\title{
The U.S. Department of Energy Wind Turbine Candidate Site Program: The Regulatory Process
}

Marjorie R. Greene

Kim R. York

June 1982

Prepared for the U.S. Department of Energy under Contract DE-AC06-76RLO 1830

Pacific Northwest Laboratory Operated for the U.S. Department of Energy by Battelle Memorial Institute 


\title{
DISCLAIMER
}

This report was prepared as an account of work sponsored by an agency of the United States Government. Neither the United States Government nor any agency thereof, nor any of their employees, makes any warranty, express or implied or assumes any legal liability or responsibility for the accuracy, completeness, or usefulness of any information, apparatus, product, or process disclosed, or represents that its use would not infringe privately owned rights. Reference herein to any specific commercial product, process, or service by trade name, trademark, manufacturer, or otherwise, does not necessarily constitute or imply its endorsement, recommeridation, or favoring by the United States Government or any agency thereof. The views and opinions of authors expressed herein do not necessarily state $\mathrm{cr}$ reflect those of the United States Government or any agency thereof.

\author{
PACIFIC NORTHWEST I.ABORATORY \\ operated by \\ BATTELLE \\ for the \\ UNITED STATES DEPARTMENT OF ENERGY \\ under Contract DE-AC06-76RLO 1830
}

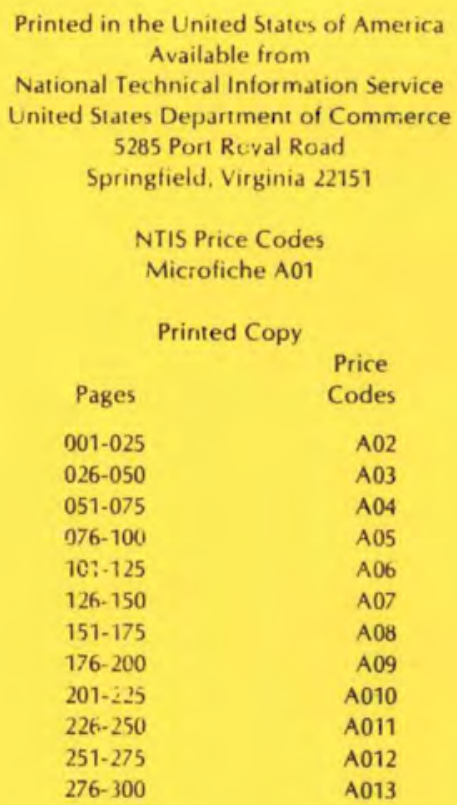


THE U.S. DEPARTMENT OF ENERGY

WIND TURBINE CANDIDATE SITE PROGRAM:

THE REGULATORY PROCESS

Marjorie R. Greene

Kim R. York

Battelle Human Affairs Research Centers

Seattle, Washington 98105

June 1982

Prepared for

Pacific Northwest Laboratory

Richland, Washington 99352

Under Agreement B-92882-A-5 of

Prime Contract DE-AC06-76RLO 1830

with the Department of Energy

Office of Solar Power Applications

Wind Energy Technology Division

Federal Wind Energy Program

Pacific Northwest Laboratory

Richland, Washington 99352 

EXECUTIVE SUMMARY

For the past six years the U.S. Department of Energy (formerly U.S. Energy Research and Development Administration) has been involved in the planning and development of wind turbines of various sizes and in the selection of candidate sites for the installation of these new turbines (U.S. Department of Energy, 1980). This report focuses on sites selected in 1979 as tentative sites for installation of a demonstration MOD-2 turbine. Selection as a candidate site in this program meant that the U.S. Department of Energy (DOE) designated the site as eligible for a DOE-purchased and installed meteorological tower.

This report examines the regulatory procedures involved in the siting and installation of these meteorological towers at the majority of the candidate sites. An attempt is also made, in a preliminary fashion, to identify the legal and regulatory procedures that would be required to put up a furbine at each of these candidate sites. The information provided on each of these sites comes primarily from utility representatives, supplemented by conversations with state and local officials.

The major findings are summarized in the paragraphs that follow. It should be apparent in this summary and the following text that the experiences of siting the towers and a large Wind Energy Conversion System (WECS) have been very individual to date. As more experience is acquired in each of the states with large WECS, the regulatory process will become more defined. 


\section{Land ownership}

- Land ownership appears to be one of the most important factors affecting regulatory requirements. Whether a turbine is on federal, state, town or privately owned land makes a significant difference in terms of compliance with environmental legislation and regulations.

\section{Federal requirements}

- Numerous federal laws can apply to the siting of a tower and a turbine, depending on the site-specific characteristics. A recent SERI report identified eighteen relevant laws (Noun et al., 1981). For the candidate sites the federal laws that most frequently applied included: National Environmental Policy Act (NEPA), Federal Aviation Administration (FAA) requirements, Historic Sites, Buildings and Antiquities Act and Endangered Species Act of 1978.

\section{State requirements}

- Only one state (Oregon) has developed siting standards for WECS to date. These standards apply to facilities with a rated capacity of 25 MWe of power or more. Several states that have siting laws for power generating facilities have cut-off points of 50 MWe or 100 MWe or more. Several states' siting laws apply only to thermal facilities. No candidate site has been regulated to date by state siting requirements, although at the time of turbine siting this may become an issue at some sites. 
- Several states have state environmental policy acts; in some cases these applied to the candidate sites. For other sites, such as Goodnoe Hills in Washington State, federal preemption (in that case because of Bonneville Power Administration and U.S. Department of Energy involvement) meant that no compliance with state regulations was required. (There, however, compliance with the A-95 review process was required; this review was administered by the State Historic Preservation Office.)

- State agencies involved in the regulation of the candidate site towers included parks departments, transportation departments, historical commissions, Fish and Game departments, coastal zone management agencies, and Natural Resources departments.

- The A-95 review process, in which state and local agencies review the proposed projects (classified as federal projects because of U.S. DOE's involvement) for any potential conflicts between state, local and federal activities, applied at several candidate sites.

\section{Local requirements}

- Many of the candidate sites needed to obtain a city, town and county building permit. In some cases the formal local permitting process did not apply because of federal or state involvement in the project, however coordination between utility and local officials was still a vital part of the process.

- Local and county zoning ordinances restricted activities for some of the utilities in the candidate site program. Again certain entities were exempt from local zoning controls. For those sites where compliance was necessary (or will be necessary for a turbine) a conditional use permit was most often obtained. 
- At one site the power of eminent domain was used to acquire the necessary land rights, since the landowner was unwilling to sell a transmission line easement to the utility. This was one of several private landowners involved in the project. Although used infrequently, a publicly regulated utility has eminent domain powers to acquire land for energy development while a private utility can use eminent domain powers for transmission line right-of-way acquisition (Noun et al., 1981:58).

- For those candidate sites where new power lines need to be installed to the turbine site, an electrical permit from the local jurisdiction will likely be required.

\section{Public attitudes}

- Public concerns with WECS have centered, to date, on aesthetic and noise issues. Most candidate sites enjoy enthusiastic support from their local communities. One former candidate site generated severe public opposition that centered on aesthetic issues (disturbance of a pristine mountain ridge view) and technical issues (possibilities of icing, fog, concern for public safety and possible conflict with a U.S. Forest Service plan for the area).

\section{Wind rights}

- Wind rights, while not a regulatory requirement, appear to be a major area of concern in the future siting of WECS; and since the turbines are not up in the candidate site program, it seemed useful to look at the issue in this context. Taken from some work 
done by the Oregon Attorney General's Office (Wind Task Force Memo, 1980) several strategies for acquiring and preserving WECS developers'access to the wind were summarized:

\section{Private Actions}

- absolute ownership (fee title acquisition) of enough surrounding property to guarantee sufficient wind in all significant wind-producing areas;

- fee title acquisition to land on which wECS installation situated and lease acquisition for sufficient surrounding property or lease aquisition to entire project area.

- acquisition of a negative easement which gives a WECS owner the legal right to prevent the adjoining landowner from obstructing the wind flow.

- establishment of a restrictive covenant, a contractual device negotiated by private parties.

\section{Public Actions}

- statutory recognition of a wind access easement (e.g., Oregon)

- establishment of a permitting system for the acquisition of wind access rights.

- the purchase of wind access easements

- the use of zoning setback requirements for WECS

- the use of eminent domain powers. 
- 


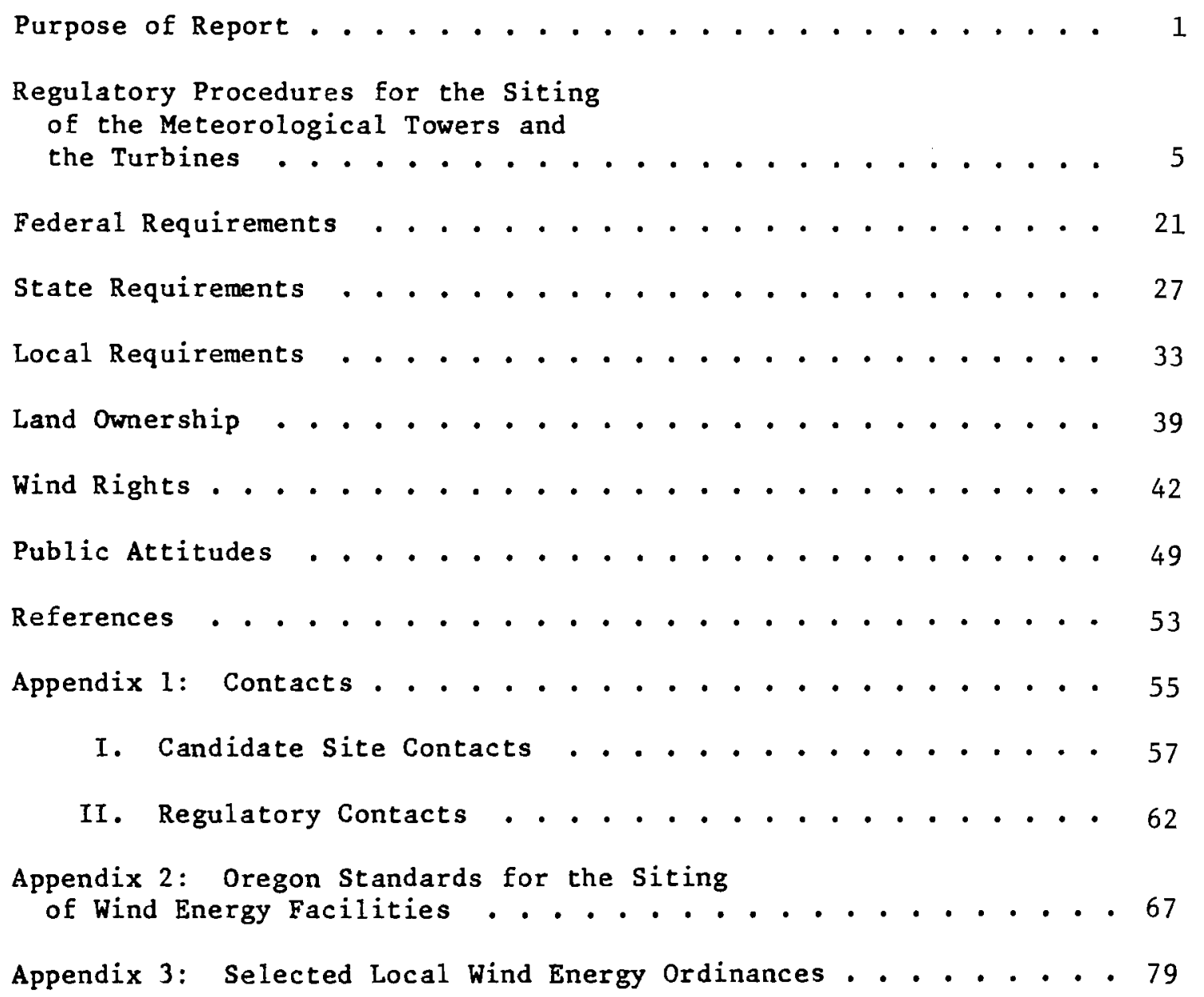


.

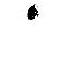


THE U.S. DEPARTMENT OF ENERGY WIND TURBINE

CANDIDATE SITE PROGRAM: THE

REGULATORY PROCESS

Purpose of Report

For the past six years the U.S. Department of Energy (formerly U.S. Energy Research and Development Administration) has been involved in the planning and development of wind turbines of various sizes and in the selection of candidate sites for the installation of these new turbines (U.S. Department of Energy, 1980). In 1976, 17 candidate sites were selected from which five sites were designated for wind turbine installation. These sites included four MOD-OA $200 \mathrm{KWe}$ wind turbines (at Culebra, Puerto Rico; Block Island, Rhode Island; Clayton, New Mexico and Kahuku, Hawaii) and one MOD-1 2000 kWe machine at Boone, North Carolina. In 1979 two Program Opportunity Notices (PON) were 1ssued: (1) to select MOD-2 tentative sites from which an installation site could quickly be picked for a cluster of up to four MOD-2 turbines, and (2) to select the actual MOD-2 installation site. This process resulted in the selection of Goodnoe Hills, Washington as the MOD-2 tentative site and the MOD-2 installation site. Twenty other sites were also selected for future wind turbine systems; these sites are the candidate sites referred to throughout this report.

Selection as a candidate site meant that the U.S. Department of Energy (DOE) designated the site as eligible for a DOE-purchased and installed meteorological tower. A detailed description of the tower and requirements for installation are provided by the U.S. Department of Energy 
(1980). Since this selection, one site has been dropped by DOE from the program (Lincoln Ridge, Vermont) and one site does not have its tower installed (Montauk Point, New York).

This report examines the regulatory procedures involved in the siting and installation of these met towers at the majority of the candidate sites.* An attempt is also made, in a preliminary fashion, to 1dentify the legal and regulatory procedures that would be required for putting up a turbine at each of these candidate sites. The information provided on each of these sites comes primarlly from utility representatives for each site, supplemented by conversations with state and local officials (see Appendix 1).

An underlying assumption of this report is that the experiences of the candidate sites may be useful to other utilities considering the siting and installation of a large WECS (Wind Energy Conversion System). The candidate sites represent a range of utility types (private, municipal, rural electric, federal) and land ownership patterns (private, municipal, state and federal). Each combination is subject to a different set of regulatory requirements. These various combinations result in a complex number of regulatory procedures that may be of interest to others in the field. In addition, the experience of siting and installing the met tower has, for some utility representatives and government officials, highlighted several issues that may be of importance to the future siting of WECS--such as wind rights and 1 and ownership.

* San Gorgonio Pass, California and Kahuku, Hawaii have not be included in these discussions. 


\begin{abstract}
Information on regulatory procedures required for the siting of met towers at each candidate site is presented in Table 1. Information on the expected procedures for siting a turbine is presented in Table 2 . Major issues that surfaces as relevant to the siting of the met towers or a WECS more broadly are treated in a discussion section following the tables.
\end{abstract}




\section{Regulatory Procedures for the}

Siting of the Meteorological

Towers and the Turbines

Table 1 summarizes the regulatory requirements of the candidate sites in putting up their met towers. For each site the utility is noted, as well as the present land ownership. Then federal, state and local requirements (statutes, permits, procedures) for each site are documented.

Table 2 summarizes the expected requirements of the same candidate sites in siting future turbines. This information is much less complete since in many cases the actual siting process has not begun. It is difficult to predict regulatory requirements for future WECS since the technology is new and there is uncertainty both among utility officials and regulatory agency officials concerning applicable procedures and permits. A major area of uncertainty involves the preparation of environmental impact assessment studies; how this is handled deperds in part upon whether the project developer is a utility or a governmental entity. Thus Table 2 should be considered a very preliminary identification of the regulatory process for siting a turbine at each of the candidate sites.

In the sections following the two tables, the major categories of information-federal, state and local requirements--are discussed in more detail. Attention is also paid to the broader issues of land ownership and utility type and how these characteristics influence the regulatory process. Wind rights and public attitudes are also discussed, since both are emerging as important issues in the siting of WECS. 
As a further point of introduction to the tables it should be pointed out that it can be a very complex task just to determine what agencies require permits for a tower or turbine. As is discussed in a recent SERI report, developers "frequently find it difficult to identify the correct agency and the correct office within that agency to which they must apply For each permit" (Welborn and Williams, cited in Noun et al., 1981:13). Thus the experiences of the DOE candidate sites may reflect some of this uncertainty that accompanies early attempts to regulate a new technology. 
TABLE 1

REGULATORY PROCEDURES FOR METEOROLOGICAL TOWERS IN THE CANDIDATE SITE PROGRAM

$\begin{array}{lc}\text { Site and Utility } & \text { Land Ownership } \\ \text { Big Sable Point, } & \begin{array}{c}\text { State Park } \\ \text { Michigan }\end{array} \\ \begin{array}{c}\text { Consumers Power } \\ \text { Company }\end{array} & \text { (Ludington State Park) }\end{array}$

Federal Requirements *

1. FAA, Aeronautical Study indicated no permit required 2. DOE Environmental Assessment
State Requirements*

1. State Park Use permit obtained from state DNR within one week. Permit process expedited because DNR was one of the applicants.

from state

3. Michigan Aeronautics Commis-

sion made a deterrainatian

that the tower did not conflict

with its rules and regulations.

\section{Bridger Butte,}

Wyoming

Intermountain Con-

sumer Power
Bureau of Land

Management
1. Needed to obtain a temporary permit from BLM; had to prepare a "temporary" site-specific EIS. Permit must be renewed yearly. Permit also authorized of that portion of the acces rood from the ccess road from the nearby
Prepared two studies for the state:

(1) archeological, and

(2) historical
No zoning in county met tower located in. No
Local Requirements *

County building pernit
Cape Blanco,

$$
\text { Oregon }
$$

Coos-Curry Elec-

tric Cooperative
State Park

(Cape Blanco State Park)
1. Notified and filed a Notice of Proposed Construction with FAM.

2. DOE Environmental Assess ment
Department of Transportation, State Parks Division, turned down lat site because visual aspects of the project would not conform with park use. The Parks Diviaion approved the Parks Division approv the 2nd site for a met tower and indicated that installation there.
1. Conditional use permit from county took 2 months because of length of time between county meetings.

2. Building permit from county took about 2 hours.

*0nly those requirements which applied at the individual site are reported on in this table. 
TABLE $1\left(\operatorname{con}^{\prime} t\right.$.)

Site and Utility

Land Ownership

Diablo Dam,

Washington

Seattle City

ight
Seattle City Light National Park
Federal Requirements

1. Park service temporary use pernit took about months. Park service urged Seattle City Light to site tower in such a manner as to have the lowest visual impact on nearby recreation areas.

2. FAA approval

3. DOE Environmental Assessment
State Requirements

Local Requirements
- Negative Declaration under Washington SEPA for the Washington State Dept. of Ecology.

2. Consultation with State Highway Dept. due to danger of tower falling across a state roadway. No danger with present site but other sites Seattle City Light had been considering were close enough to highways

to cause concern.

\section{Finley, North} Dakota

Sheyenne Valley Electric Coopera-
U.S. Air Force (abandoned Air Force base)
1. FAA was informed - needed no permit because tower not tall enough.

2. Utility obtained lease for the land from the Air force, via U.S. Department of Energy. Since it was a federal DOE program, the utility decided it would be quicker to have DOE obtain permission from Air Force for a temporary use permit. Took approximately 30 days for DOE to obtain permit. for DOE to obtain permit.
Utility tried for 3 or 4 Utility tried for 3 or 4
months to get permit from Air Force, unsuccessfully. DOE recently requested a one-year extension of the lease.

3. DOE Environmental Assessment
None
No building permit was required.

1. The major regulatory constraint was approval by the Commanding General of the base. The pro posal was circulated to the
various division commanders, the various division commanders, the firing range and airfield personnel. Once approved by the Commanding General, the proposal went before the Installation

Fort Sill,
Oklahoma
U.S. Army Field
Artillery Center
and Fort sill

ort Sill,

U.s. Army

Artillery Cen

and Fort Sill 
TABLE 1 (con't.)

Planning Board for inclusion in

the Fort Sill Master Plan.

2. FAA a pproval

3. DOE Environmental Assessment

\section{BPA owns the property upon which the tower and other facilities (including the turbines) sit, and has right-of-way $(\mathrm{R}-\mathrm{O}-\mathrm{W})$ easements for
mission $l$ ines.}

Washingtonl

Bonneville Power

Administration

\begin{tabular}{ll} 
Huron, South & \multicolumn{1}{c}{ Private } \\
Dakota & (It took 60-90 days to \\
East River Elec- & negotiate the lease \\
tric Power & agreement with the \\
Cooperative & landowner.)
\end{tabular}

1. Extensive dealings with FAA concerning tower and blade markings

2. For the turbine site, a Finding of No Significant Impact (FONSI) issued after DOE Environmental Assessment submitted to Washington, D.C. NEPA Affairs office. Environmental investigations began in July of 1979 with FoNS I being issued in December 1979. There were some archeological sites of concern and a herbaceous plant thought to be endangered. A transmission around gully in hich existed an Indian site of historical significance.
For the tower and turbines, formal compliance with Washington State Environmental Policy Act (SEPA) was not required due to federal preemption. by BPA and U.S. DOE involvement ${ }^{2}$. However BPA had formal consultations with federal and state agencies, including State Historic Preservation office and Fish and Wildlife, to comply with A-95 review. . Formal negotiations landowner completed in approximately 4 months, preceded by many months of informal discussion. Transmission line easements also had to be obtained from 3 other landowners. A separate easement agreement was consummated for small land parcel for a remote communication facility.

4. Rlickitat County building permit took about a week to obtain.

\author{
1. FAA permit (submitted a \\ form which PAA approved) \\ EIS required because they \\ need no loan funds) \\ 3. DOE Environmental Assess- \\ m. " \\ None
}

1. Building permit required for cons

2. Existing zoning classification allowed a tower, so no variance or cond itional use permit required. 3. Lease agreement with land
owner took 60-90 days.

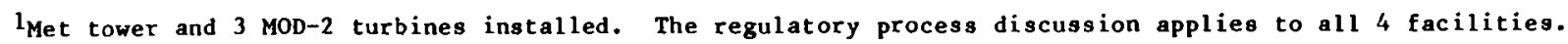

${ }^{2}$ Noun, Robert J.; Michael Lotker and H. Paul Friesema. 1981. Utility Siting of WECs: A Preliminary Legal/Regulatory Assessment. SERI/TR-744-788. Golden, Colorado: Solar Energy Research Institute. 
TABLE 1 ( $\operatorname{con}^{\prime} t$.)

Ilio Point, Hawai Molokai Electric Co.
Private for the met tower location. Some possiwould be located on Coast Guard land. bility that turbine
2. DOE Environment Assessment

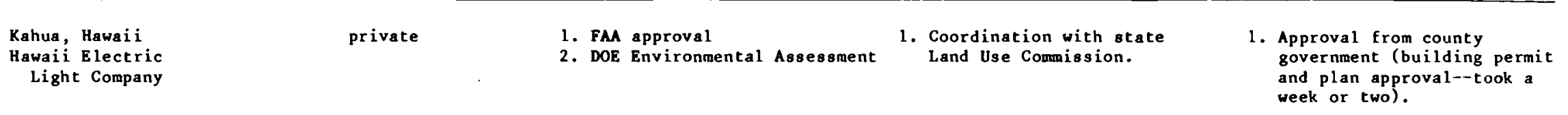

$\begin{array}{cc}\text { Lincoln Ridge, } & \text { U.S. Forest Service } \\ \text { Vermont } & \text { (Green Mountain National } \\ \text { Green Mountain } & \text { Forest) }\end{array}$

reen Mountain

Power Corporation
(Green Mountain National Forest)
1. FAA clearance

2. DOE Envirancen ment led to issuance of Finding of No Significant Impact (FONSI) on January 21,1981 by the NEPA Affair Division, Office of Environmental Compliance and Overview, U.S. Department of Energy, Washington, D.C.
1. Land Use Commission had to approve zoning conformance. (The land is zoned agricultural and WECS are now considered a permitted use in an agricultural zone.)

\section{See discussion under "Stratton Mountain". \\ The Forest Service took the legal position the Vermont Act 250 did not apply to \\ Forest Service land. This apparent conflict with state environmental controls prompted a ruling on the issue by the Vermont Environmental Board. On Nov. 17, 1980, the Board ruled that the met tower is \\ a federal research project \\ on federally-owned 1 and and \\ is therefore outside the jurisdiction of Act 250 .}

None
1. Easement from the 1 and

ty building permit 3. Subdivision permit

\begin{tabular}{|c|c|c|c|c|}
\hline $\begin{array}{l}\text { Livingston, } \\
\text { Mont ana } \\
\text { Montana Power } \\
\text { Company }\end{array}$ & $\begin{array}{l}\text { Private } \\
\text { (MPC has lease and ease- } \\
\text { ment) }\end{array}$ & $\begin{array}{l}\text { FAA approval took about } 1 \\
\text { month to evaluate how } \\
\text { turbine might interfere } \\
\text { with nearby airport. }\end{array}$ & None & $\begin{array}{l}\text { City building permit for } \\
\text { tower construction was } \\
\text { obtained in approximately } \\
\text { l week. }\end{array}$ \\
\hline $\begin{array}{l}\text { Meade, Kansas } \\
\text { City of Meade }\end{array}$ & $\begin{array}{l}\text { Private } \\
\text { (It took } 12 \text { weeks to sign } \\
\text { the land leases and ease- } \\
\text { ments with the property } \\
\text { owners.) }\end{array}$ & $\begin{array}{l}\text { 1. FAA permit - clearance } \\
\text { from the airport took } \\
\text { approximately } 6 \text { weeks. } \\
\text { Also received clearance } \\
\text { from cable TV company. }\end{array}$ & $\begin{array}{l}\text { 1. State Department of Trans- } \\
\text { portation: rights-of-way } \\
\text { along state highways for } \\
\text { the transmission lines } \\
\text { took } 8 \text { weeks to obtain. }\end{array}$ & $\begin{array}{l}\text { 1. A-95 clearinghouse review. } \\
\text { Any development must do an } \\
\text { environmental assessment. } \\
\text { Planning commission } \\
\text { reviewed it first, then }\end{array}$ \\
\hline
\end{tabular}

${ }^{3}$ Tower proposed but lost DOE funding before it could be installed. Utility may proceed with project with its own funding. 
TABLE 1 (con't.)

2. DOE Environmental Assessment
2. State agencies had input into A-95 clearinghouse into a-gs clearinghouse issues: historical resources, wildlife (birds in particular), vegetation, forestry and air quality. distributed it to state agencies for review. The entire process took approximately 6 weeks.

2. Leases and easements took approximately 12 weeks to
Minot Radar, North Dakota

Verendrye Electric
U.S. Department of Defense
- Submitted information to FAa, but permit not

DOE obtained the lease

agreement from DOD (similar

to situation deacribed for

Finley, N.D.). It took a

couple of months for DOE

to negotiate the agreement;

if the utility had wanted to

obtain a lease agreement,

the process would have taken

at least 1 year.

. DOE Environmental Assess-
Cleared project through North Dakota Historical Society

None

\begin{tabular}{|c|c|c|c|c|}
\hline $\begin{array}{l}\text { Montauk Point, New } \\
\text { York } 4 \\
\text { Long Island Lighting } \\
\text { Company }\end{array}$ & $\begin{array}{l}\text { State Park } \\
\text { (Montauk State Park) }\end{array}$ & $\begin{array}{l}\text { 1. FAA approval } \\
\text { 2. DOE Environmental Assess- } \\
\text { ment }\end{array}$ & $\begin{array}{l}\text { Coordination with State Parks } \\
\text { officials }\end{array}$ & $\begin{array}{l}\text { Town building permit includes: } \\
\text { a. Town permission } \\
\text { b. Possible compliance with } \\
\text { East Hampton, N.Y. WECS } \\
\text { zoning ordinance amend- } \\
\text { ment (presently in } \\
\text { draft form). }\end{array}$ \\
\hline $\begin{array}{l}\text { Nantucket, } \\
\text { Massachusetts } \\
\text { Nantucket Electric } \\
\text { Company }\end{array}$ & $\begin{array}{l}\text { Town-owned land leased } \\
\text { to the utility. }\end{array}$ & $\begin{array}{l}\text { 1. FAA was informed - no } \\
\text { permit needed because } \\
\text { of height } \\
\text { 2. DOE Environmental Assess- } \\
\text { ment }\end{array}$ & $\begin{array}{l}\text { Endangered species (plant): } \\
\text { State environmental } \\
\text { personnel determined that } \\
\text { the endangered plant could } \\
\text { co-exist on the site with } \\
\text { the met tower and any } \\
\text { future turbine. }\end{array}$ & $\begin{array}{l}\text { 1. Historical Districts } \\
\text { Commission approval was } \\
\text { obtained in about a week. } \\
\text { 2. Waiver by local Zoning } \\
\text { Board of } 30 \mathrm{ft} \text {. height } \\
\text { limitation. }\end{array}$ \\
\hline
\end{tabular}

${ }^{4}$ Refers to regulatory process for 2 nd candidate site meteorological tower that has not been installed due to delays in the regulatory process. The first met tower was installed in 1976 on a site owned by the New York Ocean Sciences Laboratory. 
TABLE $1\left(\operatorname{con}^{\prime} t\right.$.)

Site and Utility

Pacheco Pass,

Cali fornia

Cal ifornia Department

of Water Resources

State-owned land. DWR had, 4 years previously, sold land Fish and Game. Written interagency agreement obtained between the 2 agencies.

\section{Federal Requirements}

Filed with the FAA. Didn't need a permit because they are not ear an airport and not tall enough.

2. DOE Environmental Assessment
1. Filed a notice of exemption for the California Environmental Quality Act
(CEQA) that took about 90 (CEQA) that took about 90 days to obtain.

2. State Dept. of Parks assured compliance with National historic Preservation Act.

3. Interagency agreement (discussed under land ownership) took 45 days.

\begin{tabular}{|c|c|c|c|c|}
\hline $\begin{array}{l}\text { Provincetown, } \\
\text { Massachusetts } \\
\text { New Bedford Gas \& } \\
\text { Edison Light Co. }\end{array}$ & Town-owned & $\begin{array}{l}\text { 1. FAA approval was a long } \\
\text { and involved process due } \\
\text { to close proximity of air- } \\
\text { port (I mile). Tower had } \\
\text { to be lowered from } 160 \mathrm{ft} \text {. } \\
\text { to } 140 \mathrm{ft} \text {. to satisfy FAA } \\
\text { concerns. } \\
\text { 2. DOE Environmental Assess- } \\
\text { ment }\end{array}$ & None & $\begin{array}{l}\text { 1. Town building permit } \\
\text { 2. Permission from town to } \\
\text { use site. }\end{array}$ \\
\hline $\begin{array}{l}\text { San Augustin Pass, } \\
\text { New Mexico } \\
\text { E1 Paso Electric } \\
\text { Company }\end{array}$ & $\begin{array}{l}\text { Temporary outgrant from } \\
\text { U.S. Army White Sands } \\
\text { Missile Range }\end{array}$ & $\begin{array}{l}\text { 1. Land outgrant } \\
\text { 2. FAA approval was quick to } \\
\text { obtain because the military } \\
\text { base has restricted air- } \\
\text { space. } \\
\text { 3. DOE Environmental Assess- } \\
\text { ment: main roadblock was } \\
\text { archeological approval, } \\
\text { the entire process lasting } \\
\text { about a month. }\end{array}$ & $\begin{array}{l}\text { Consultation with state Dept. } \\
\text { of Game and Fish personnel } \\
\text { concerning impact of tower } \\
\text { on resident bighorn sheep. }\end{array}$ & None \\
\hline
\end{tabular}

\section{Stratton Mountain,} Vermont

Vermont Electric Cooperative, Inc.
St. Regis Paper -

Vermont Electric Coop. has 4-year lease.
1. FAA clearance

Assesment
Vermont Act 250 (10 V.S.A. Chapter 151) requires any project that results in land use changes to undergo an environmental reviev through an administrative hearing process. One cri terion of the Act is that proposals for development above 2500 feet in elevation must go before the Regional Environmental Board for
DWR consulted with the county. No zoning or building permits required because ments from St. Regis Paper and the Stratton Mountain Corporation 
TABLE 1 (con't.)

Site and Utility

Land Ownership
State Requirements

Local Requirements

approval. The Board is a

one-stop permitting agency

and coordinates input from

all other concerned agencies.

A "minor section" Act 250

permit was obtained smoothly,

(in a matter of a few months)

becsuse of the minimal envi

opposition.
Tucumcari, New Mexico

City of Tucumcari/

Tuc uncari Munici-

pal Power Company

(now run by South-

western Public

Service Company)



Wells, Nevada

Wells Rural Electric

Company
Private

1. FAA - phone call secured approval

2. DOE Environmental Assessment
1. State building permit took approximately $21 / 2$ weeks

. Completion of DOE's environ

mental assessment with an

archeological site survey was

necessary to satisfy the A-95

review requirement imposed by

the New Mexico Historic Preser-

vation Bureau.
Property owner usage agreement
Coordination of State Fish \& Game officials with BLM

- BLM temporary use permi issued in about 2 weeks

2. FAA approval

3. DOE Environmental Assess-
None identified in interview

ment by BLM 
TABLE 2

EXPECTED REGULATORY PROCEDURES FOR TURBINES

IN THE CANDIDATE SITE PROGRAM

Site and Utility

Big Sable Point, Michigan Consumers Power Company

\section{Federal Requirements*}

FAA permit and compliance with AA regulations

\section{State Requirements*}

1. State Park use permit

2. Michigan Environmental Policy Act compliance

3. Possible Sand Dune Protection and Management Act (Act 222, PA 1976) application for excavation in dunes area. The Act was deemed not to apply to installation of the meteorological tower, but may apply

to turbine construction activi-

$$
\text { ties. }
$$

4. Possible Michigan Coastal Zone Management Act application
Bridger Butte, Wyoming Intermount ain Consumer
Hould have to comply with federal EIS requirements and prepare an EIS for the entire butte.
1. Electrical permit from Wyoming Department of Fire Prevention and Electrical Safety

2. Possible State Environmental Policy Act application

\begin{tabular}{|c|c|c|}
\hline $\begin{array}{l}\text { Cape Blanco, Oregon } \\
\text { Coos-Curry Electric } \\
\text { Cooperative }\end{array}$ & Possible FAA permit & $\begin{array}{l}\text { Energy Facility Siting Council } \\
\text { process if project more that } \\
25 \text { HW (see discussion under } \\
\text { Boardman, oregon and } \\
\text { Appendix } 2 \text { ). }\end{array}$ \\
\hline
\end{tabular}

The state Land Conservation and Development Commission (LCDC) has given Curry County permission to issue permits for HECS in exclusive farm use zones (EFU zones). In other zones, because the county is currently in a building moratorium the utility or developer would need to developer would need to get approval from the State Land Conservation and Development
Commission (LCDC).

* Only those requirements which would apply at the individual site are reported on in this table. 
TABLE 2 (con't.)

Site and Utility

Diablo Dam, Washington Seattle City Light
Federal Requirements

1. Park Service use permit

2. FAA approval and compliance with regulations
State Requirements

Local Requirements

1. Compl iance with Washington State Environmental Policy Act (SEPA) administered by Washington State Dept. of Ecology

2. Consultation with State Highway Dept. to satisfy distance requirements from state highways

3. Posaible siting law application if large enough WECS array

\begin{tabular}{|c|c|c|c|}
\hline $\begin{array}{l}\text { Finley, North Dakota } \\
\text { Sheyenne Valley Electric } \\
\text { Cooperative }\end{array}$ & $\begin{array}{l}\text { 1. Would need FAA permit. } \\
\text { 2. Would need lease for the land. } \\
\text { Air Force should transfer } \\
\text { land to GSA. GSA would then } \\
\text { lease to the utility. } \\
\text { However Air Force has still not } \\
\text { decided what they want to do } \\
\text { with the property, so at this } \\
\text { point it is not clear if lease } \\
\text { would come from Air Force or GSA. }\end{array}$ & & . \\
\hline $\begin{array}{l}\text { Fort Sill, } \\
\text { Ok lahoma } \\
\text { U.S. Army Field Artillery } \\
\text { Center and Fort Sill }\end{array}$ & $\begin{array}{l}\text { 1. Approval by Fort sill Gommanding } \\
\text { General } \\
\text { 2. FAA permit and compliance with } \\
\text { regulations (will require marking } \\
\text { and lighting). }\end{array}$ & None & None \\
\hline $\begin{array}{l}\text { Huron, South Dakota } \\
\text { East River Electric } \\
\text { Power Cooperative }\end{array}$ & $\begin{array}{l}\text { 1. Would have to comply with federal } \\
\text { EIS requirements because they } \\
\text { are a rural electric coopera- } \\
\text { tive and have a mortgage } \\
\text { agreement with REA. } \\
\text { 2. FAA approval and pliance } \\
\text { with regulations }\end{array}$ & $\begin{array}{l}\text { 1. Siting law in S. D. currently } \\
\text { applies to facilities larger } \\
\text { than } 50 \text { HW. It would apply } \\
\text { to a large array of WECS. If } \\
\text { project required transmission } \\
\text { lines greater than } 115,000 \\
\text { volts, it would also be sub- } \\
\text { jected to state siting require- } \\
\text { ments. } \\
\text { 2. Possible South Dakota Environ- } \\
\text { mental Policy Act application }\end{array}$ & $\begin{array}{l}\text { 1. Construction permit from } \\
\text { County Planning and zoning } \\
\text { Board } \\
\text { 2. Change of present zoning } \\
\text { classification from County } \\
\text { Planning and Zoning Board. } \\
\text { 3. County franchise from the } \\
\text { County Commission to con- } \\
\text { struct any necessary } \\
\text { transmission lines. }\end{array}$ \\
\hline
\end{tabular}


TABLE 2 (con't.)

\section{Site and Utility}

Ilio Point, Hawai i

Molokai Electric Co.

ine is located on federal land would require approval of the Coast Guard. Might also

require "debombing"

2. Possible FAA permit

\section{State Requirements}

1. Possible permit by State Dept. of Land and Natural Resources if turbine located in corgervation district.
Local Requirements

1. Would likely need a building permit

2. Determination by county if an EIS required or not.
Rahua, Hawai i

Hawaii Electric Light

1. Possible FAA approval

Company
1. Wind turbines an approved use in agricultural zones--would not likely need permit.
1. County approval (plan approval, special permit, building permit)

2. Lease and easements from land owner.

3. Posgible EIS requirement negative declaration negative declaration (from likely would be negative likely would be negative declaration since turbine would be on agricultura land, an approved use.
Lincoln Ridge, Vermont Green Mountain Power Corporation.

1. FAM approval and compliance with regulations

2. Federal EIS required due to public opposition over visual impact

3. U.S. Porest Service opecial use permit
1. See discussion under "Stratton Mountain". State PUC review compliance will be required.

2. Possible siting law application if large enough WECS array

\begin{tabular}{|c|c|c|c|}
\hline $\begin{array}{l}\text { Livingston, Montans } \\
\text { Montana Power Company }\end{array}$ & $\begin{array}{l}\text { FAA permit and compliance with } \\
\text { regulations }\end{array}$ & $\begin{array}{l}\text { 1. Possible Major Facilities } \\
\text { Siting Act application if } \\
\text { large enough WECS array } \\
\text { 2. Possible Montana Environ- } \\
\text { mental Policy Act applica- } \\
\text { tion }\end{array}$ & $\begin{array}{l}\text { 1. Landowner approval-- new } \\
\text { lease and easement agree- } \\
\text { ments needed. } \\
\text { 2. City building permit }\end{array}$ \\
\hline $\begin{array}{l}\text { Meade, Kansas } \\
\text { City of Meade }\end{array}$ & $\begin{array}{l}\text { FAA permit (city received } \\
\text { verbal clearance for a } \\
\text { turbine--both in terms of } \\
\text { flight pattern and distance } \\
\text { from airport.) }\end{array}$ & $\begin{array}{l}\text { Posaible Electrical Siting and } \\
\text { Generating Act compliance if } \\
\text { large enough WECS array. } \\
\text { Present cutoff is } 50 \text { for } \\
\text { interconnection to the grid. }\end{array}$ & \\
\hline
\end{tabular}


TABLE 2 (con't.)

Site and Utility

Minot Radar, North Dakota

Verendrye Electric Cooperative, Inc.
Federal Requirements

DOD will only grant a lease to the utility and will not let them acquire site. GSA and Corps of Engineers would have responsibility for the site once DOD disposes of it; after it goes to GSA they have

a year to dispose of it.

Process of obtaining site from

GSA should be reasonably short.
1. FAA permit and compliance with regulations

Montauk Point, New Yor Long Island lighting Company

2. Possible GSA approval if U.S. Government land at Ft. Hero is involved

3. U.S. Coast Guard approval. The U.S. Coast Guard Station at Montauk Point maintains a radio transmitter and receiver at the eastern border of the at the eastern border of the proposed Montauk Point site. review and aprove any new review and approve any new construction within a radius of $1000 \mathrm{ft}$. from their radio beacon, transmitter and receiver that may affect the radiation pattern, radiated power or result in increased received noise.

\section{State Requirements}

Local Requirements
FAA permit and compliance with regulations
1. Possible State Park use permit

2. Compliance with N.Y. State Environmental Quality Review Act

3. Possible siting law application but currently applies

to facilities larger than$$
50 \mathrm{mH} \text {. }
$$

Town building permit includes:

- Town permission

b. Compliance with East Hampton, N.Y. WECS zoning ordinance agreement.
Nantucket, Massachusetts Nantucket Electric Company
1. Coordination with state environmental personnel on location of endangered plant 2. Possible siting law applica tion if large enough WECS array
1. Historic Districts Commission approval can take up

2. Zoning Board approval. The zoning board is currently waiving the $30 \mathrm{ft}$. height linitation but an ordinance may be drafted within the
year to regulate WECS. Pacheco Pass, Cal ifornia
California Department of
Water Resources
FAA permit and compliance with regulations
1. If DWR wants to obtain permanent title to the land (which is likely with a turbine) they would probably exchange the would probably exchange 
TABLE 2 (con't.)

Site and Utility
Federal Requirements
State Requiremente

Local Requirements

2. CEQA requirements--would need to conduct an initial study to etermine if an tive declaration required.

\begin{tabular}{|c|c|c|c|}
\hline $\begin{array}{l}\text { Provincetown, } \\
\text { Massachusetts } \\
\text { New Bedford Gas \& } \\
\text { Edison Light Company }\end{array}$ & $\begin{array}{l}\text { FAA permit and compliance with } \\
\text { regulations }\end{array}$ & $\begin{array}{l}\text { Possible siting law application } \\
\text { if large enough wECS array }\end{array}$ & $\begin{array}{l}\text { 1. Town building permit } \\
\text { 2. Lease from town }\end{array}$ \\
\hline $\begin{array}{l}\text { San Augustin Pass, New } \\
\text { Mexico } \\
\text { El Paso Electric } \\
\text { Company }\end{array}$ & $\begin{array}{l}\text { 1. Permanent outgrant of land } \\
\text { from U.S. Army White Sando } \\
\text { Missile Range } \\
\text { 2. FAA approval }\end{array}$ & $\begin{array}{l}\text { 1. Coordination with State Dept. } \\
\text { of Game and Fish personnel } \\
\text { concerning impact to desert } \\
\text { bighorn sheep population in } \\
\text { the San Andres wountains } \\
\text { 2. Possible siting law application } \\
\text { if large enough weCS array }\end{array}$ & \\
\hline $\begin{array}{l}\text { Stratton Mountain, } \\
\text { Vermont } \\
\text { Vermont Electric } \\
\text { Company }\end{array}$ & $\begin{array}{l}\text { FAA approval and compliance with } \\
\text { regulations }\end{array}$ & $\begin{array}{l}\text { 1. } 30 \text { VSA } 248 \text { requires a "cer- } \\
\text { tificate of public good" } \\
\text { for any kind of electrical } \\
\text { generating facility. This } \\
\text { is a one-stop permitting } \\
\text { process administered by the } \\
\text { State Public Service Board. } \\
\text { Forty-five days before the } \\
\text { petition is submitted to the } \\
\text { Board, the developer must sub- } \\
\text { mit plans to the local and } \\
\text { regional planning commissions. } \\
\text { Once the petition is in, there } \\
\text { must be } 30 \text { days notice before } \\
\text { a public hearing is held. This } \\
\text { means that there is a minimum of } \\
75 \text { days for the permit and a } \\
\text { maximum of a year or more, } \\
\text { depending on public opposition. } \\
\text { 2. Possible siting law application } \\
\text { if large enough wEcs array }\end{array}$ & $\begin{array}{l}\text { Lease and access easements from } \\
\text { St. Regis Paper and the } \\
\text { Stratton Mountain Corpora- } \\
\text { tion }\end{array}$ \\
\hline
\end{tabular}


Site and Utility

Tucumcari, New Mexico City of Tucumcari/

Tucumcari Municipal

Power Company

(now run by Southwestern

Public Service Company)

Wells, Nevada

Wells Rural Electric Company

1. FAA permit and compliance with regulations

. BLM land grant or uoe agree-

ment and easements

3. BLM evaluation of projects

noncompliance with visual

resource management (VRM)

requirements.
State Requirements

1. Construction permit

2. Posaible ating law application if large enough wECS

3. Compliance with A-95 review requirement imposed by the

New Mexico Historic Preservation Bureau.

\section{Possible siting law application}

if large enough WECS array
Local Requirements

Electrical permit 



\section{Federal Requirements}

As the tables illustrate, the experiences of the candidate sites in putting up their towers, and the expected procedures for siting the turbines, vary extensively based on the nature of the utility and the land ownership. While it is impossible to generalize necessary federal requirements for any site based on the experiences of just the candidate sites, it is possible to briefly summarize the major federal issues that appear important for the siting of a WECS.

There are a host of federal statutes that may apply to the siting of a large WECS, including the Wilderness Act of 1964, the Endangered Species Act of 1978, the National Environmental Policy Act (NEPA) and the Historic Sites, Buildings and Antiquities Act. A thorough discussion of applicable statutes is contained in Noun, Latker and Friesema (1981) and Mayo, et al. (1977). These statutes affect the selection of a site, as well as dictate the government entities that would be involv'd in site selection (e.g., Indian Lands Act, Rivers and Harbors Act of 1899). In the cases of the candidate sites many of these statutes did not apply because of individual site and utility characteristics.

An example of a site where a range of federal statutes applied is the Goodnoe Hills site in Washington State, where three MOD-2 turbines have been installed. Because of the turbine installation, the experience there is more complete than at other candidate sites. To comply with NEPA, an Environmental Assessment (EA) was prepared by the U.S. Department of Energy and submitted to the Washington D.C. NEPA Affairs Office. The EA was used to coordinate the A-95 review and consultation with federal, state and local agencies. A Finding of No significant 
Impact (FONSI) was issued based on recommendations of affected agencies. There were some archeological sites of concern and a herbaceous plant thought to be endangered. An archeological survey was prepared by BPA. According to a BPA official, a transmission line was relocated to avoid a gully in which an Indian site of historical significance existed. Also, the U.S. Fish and Wildlife Service determined that because of the nature of the site, the turbine would not present an obstacle to migratory birds (Noun et al., 1981:44).

Specific federal acts that applied for other candidate sites varied, depending on the unique circumstances at each site. An Environmental Assessment (EA) was required for each site to comply with NEPA. As sponsor of the candidate site program, the U.S. Department of Energy was responsible for ensuring the preparation of these documents. All EAs for the candidate sites found that the towers would not constitute a major federal action significantly affecting the quality of the human environment, and therefore would not require the preparation of a full environmental impact statement (EIS). The turbines, however, might require an EIS, depending upon such factors as the nature of the installation, the applicable federal or state environmental review process, and land and utility ownership.

An important point to note here is that the nature of the particular project will determine whether an EA or full-scale EIS will be required to comply with NEPA. If the project involves a federal power marketing agency (such as the Bonneville Power Administration) or is located on federally owned lands (such as the Bureau of Land Management) or is sponsored by a federal agency (such as the U.S. Department of Energy or 
Bureau of Reclamation), then compliance with NEPA and CEQ regulations will be required. Whether a full-scale EIS would be required depends on the finding of the EA. Thus rural electric cooperatives, which are regulated by the Rural Electrification Administration, would be required to comply with NEPA, as well as a private utility wishing to install a WECS on land owned, for example, by BLM or the U.S. Department of Defense. Also, if any segment of a WECS transmission line traverses federal land, it is likely that compliance with NEPA will be required. It is also possible that a project might not be required to comply with NEPA but would be required to comply with a state environmental policy act.

The Federal Aviation Administration also imposed requirements at the candidate sites. Since FAA regional offices have discretion over requirements for permits for towers less than 200 feet, depending on the region some sites obtained permits for their towers and others did not. For example at the Minot Radar site, Finley site, Pacheco Pass site, Nantucket site and Tucumcari site, the FAA was notified but no permit was required. However a permit was required for several other towers, including the Meade site, Livingston site and Provincetown site. In fact in Provincetown, because of the site's location one mile from an airport, the tower was lowered from 160 feet to 140 feet to satisfy FAA concerns. Presumably any WECS over 200 feet would require a permit from the regional FAA office.

The Historic Sites, Buildings and Antiquities Act applied at several of the sites and was administered through state agencies. The Minot Radar site was cleared, for example, through the North Dakota Historical 
Society; for the Pacheco Pass site in California the State Department of Parks assured compliance with this federal act.

A range of federal regulations also applied at those candidate sites where the land is federally owned and the developer a non-federal utility. Several of the candidate sites were located on federal military property and needed to obtain special permits to operate the met towers (e.g. Minot Radar, North Dakota; Finley, North Dakota; San Augustin Pass, New Mexico; Fort Sill, Oklahoma). In most of the cases it proved easier for the U.S. Department of Energy, as the primary funding source for the candidate site program, to obtain a lease or other use agreement with the appropriate federal organization--e.g. U.S. Army or Air Force. Evidently an agreement between two federal agencles is easier to secure than an agreement between a federal agency and a private entity. Complicating the situation at the two North Dakota sites was the fact that neither property had been turned over to the GSA, the agency that will ultimately administer (or dispose of) the property. Officials for the utility at the Minot Radar site estimated that it took several months for DOE to obtain the permit; if the utility had obtained the lease it would have taken at least one year. In the case of Fort Sill, Oklahoma, the Army base itself drafted the proposal for the met tower and the main regulatory constraint involved was approved by the Fort Sill Commanding General.

Federal land ownership surfaced as an issue at the Lincoln Ridge where the U.S. Forest Service (owners of the property) took the position that state regulatory requirements (Vermont Act 250) did not apply to them. For the several candidate sites where the Bureau of Land 


\begin{abstract}
Management (BLM) owns the site, installing the met towers proved to involve few regulatory constraints. For the Bridger Butte site in Wyoming the utility obtained a temporary permit from the regional BLM office which must be renewed annually. In order to obtain the permit for the tower a small site-specific EIS had to be prepared. At the Wells Nevada site a temporary use permit was issued from the local BLM office in about two weeks.
\end{abstract}


. 


\section{State Requirements}

Oregon is the only state that currently has siting standards for WECS; their standards apply to a system that is 25 MWe or greater, and a utility or individual complies by obtaining a permit from the state Energy Facility Siting Council. (See Appendix 2 for a copy of the standards.) The candidate site in Oregon would not be required to go through this process if only one turbine is installed at the site. The Siting Council acts as a one-stop permitting body; input into the permitting process comes from all other state and local agencies, and the permit can be conditioned upon compliance with local requirements, for example. If a project does not go through the siting council, a utility or individual is obligated to obtain all state and local permits separately.

In putting up the met towers several of the candidate sites fell under the jurisdiction of a state environmental policy act. At the Pacheco Pass site, for example, the developer (State Department of Water Resources) filed a notice of exemption under the California Environmental Quality Act (CEQA). According to CEQA, certain types of projects are exempt, including data collection projects such as seismic stations and met towers. If the developer decides to put up a turbine, DWR will be required to conduct an initial study from which a decision is made to do an environmental impact report (EIR) or a negative declaration. According to a DWR official a recent proposal by a utility in California, Pacific Gas and Electric, for a cluster of turbines near Altamont Pass in Alameda County, received a negative declaration from the county, the lead agency in that case in making the determination. 
In some states there is no energy facility siting law that would apply to a WECS, nor do all states have environmental policy acts. For example, in South Dakota, if a turbine goes up at the Huron site, even though there is a state siting law it would not apply because the statute only governs facilities that generate more than 50 MWe. In Kansas, where the state siting law would also not apply to facilities less than 50 MWe, a state official raised the interesting question of how to regulate clusters of turbines or the sequential siting of turbines. The 50 MWe cutoff applies only to interconnection to the power grid, and it is possible that interconnection at more than one point may circumvent this regulatory requirement (provided each tie-in point is less than 50 MWe).

In some states, depending on the land and utility ownership configurations, a state siting law or environmental policy act might not apply because of federal preemption. However, in most cases that involve federal funding or project control the A-95 review process still applies. This was the case with the Goodnoe Hills site in Washington State; although the state has a State Environmental Policy Act (SEPA), a formal designation of compliance was not required due to federal preemption by BPA and the U.S. DOE. However, BPA in its environmental and A-95 review processes routinely contacts appropriate state agencies for their input.

Federal preemption over state statutes also surfaced as an issue at the Lincoln Ridge site in Vermont. (This site has since been dropped from the DOE program.) The state of Vermont has a state land use and development act entitled Act 250 (10 V.S.A. Chapter 151) which requires any project that results in land use changes of specified magnitude to 
undergo an environmental review through an administrative hearing process. One criterion of the Act is that proposals for development above 2500 feet in elevation must go before the Regional Environmental Board for approval. In the case of Lincoln Ridge, the U.S. Forest Service (owners of the land) took the position that Vermont's Act 250 did not apply to projects on their land. This apparent conflict with state environmental controls prompted a ruling by the Vermont Environmental Board which stated that the met tower was a federal research project on federally-owned land and was therefore outside the jurisdiction of Act 250. Now that the Lincoln Ridge site has been dropped from the U.S. DOE program, the element of federal control has been removed as an issue, and the Regional Environmental Board will be required to rule again on the applicability of Act 250. The question remains unsettled; the U.S. Forest Service is adamant that they have control while the state seems to feel that there is a chance Act 250 will apply with a private developer (Green Mountain Power) on federal land.

In the state of Hawaii the determination of whether a project requires an EIS or not is made on geographical and administrative grounds, not on such issues as size of project. Chapter 343, Hawaii Revised Statutes refers to four geographical designations and one administrative category. The four geographical designations generally are: lands in a conservation district as specified by the State Land Use Commission; lands within the defined shoreline area or within 300 feet seaward of the shoreline area; lands within any historic site; and lands within the Waikiki-Diamond Head area of Oahu. The fifth category relates to actions for which a County general plan amendment is proposed or 
required under County ordinance and which would result in a designation other than agricultural, conservation, or preservation. These are the five classes of action which subject an applicant to an EIS requirement, provided also that approval of an agency is required and that the agency finds that the proposed action may have significant environmental effects. (It is of interest to note that a wind turbine is an approved use within areas that have an agricultural designation, thus not requiring a conditional use permit.)

Depending on the location of the site, other state departments that may have jurisdiction in the WECS siting process include a parks department, transportation department, department of Game and/or Fish, and a coastal zone management agency. For example, at the Meade, Kansas site the state Department of Transportation issued the rights-of-way along state highways for the transmission lines (in anticipation of a turbine). The State Parks Division of the Department of Transportation in Oregon has veto rights, through not issuing permits, over energy facility sites less than 25 MWe proposed on state park land. (For energy facilities that are 25 MWe or greater, the State Energy Facility Siting Council makes the ultimate decision. As part of their decision process, however, other state agencies including the Department of Transportation would be asked to comment.) One measurement site in Oregon was not approved by the State Parks Division because officials feared that visual aspects of the project (particularly the turbine itself) would not conform with park use; the second site was approved for a met tower and will be considered for a turbine. At the San Augustin Pass site the state (New Mexico) Department of Game and Fish was consulted to determine 
the impact of the tower on resident bighorn sheep. The State Highway Department had to be consulted during selection of the Diablo Dam site because of liability concerns if a tower ever fell across a state highway. Ultimately the site selected by Seattle City Light was far enough away from any state highway that this was not a concern. While no coastal zone agencies were involved in the siting of the candidate sites' meteorological towers (with the possible exception of Michigan's Department of Natural Resources), state coastal zone management agencies would have jurisdiction over WECS located in the designated coastal zones. In Rhode Island, for example, one observer felt that although technically the coastal zone agency requires permits for construction within 200 feet of the ocean, in actuality they have jurisdiction over the entire state and would probably get involved in any future large wind facility. The agency would be concerned with visual impact as well as terrestial ecology impact, and for a arge unit or cluster of units it probably would take 6-8 months to obtain the permit due to the necessity for public hearings. A coastal zone requirement in Michigan is the Sand Dune Protection and Management Act administered by the state Department of Natural Resources. It was determined that a sand dune mining permit was not required for installation of a met tower at the Big Sable Point site, however such a permit may be required for a turbine there. In California a staff member at the California Energy Comnission felt it would be highly unlikely that a turbine would ever be sited in the coastal zone, which is regulated by the California Coastal Comnission. 
Another state requirement for several sites (Meade, Kansas; Tucumcari, New Mexico; Goodnoe Hil1s, Washington) was the A-95 Clearinghouse Review. A-95 is a circular promulgated by the federal Office of Management and Budget which requires state and regional review of federal projects to determine if there are potential conflicts with the activities of state and local entities. It is required for most direct federal construction or federally funded construction. In Kansas the Southwest Management Group, a regional planning body, received the environmental assessment for the Meade site and distributed it to various state agencies for approval. State agency review focused on the following issues of concern: historical resources, wildlife (particularly interested in birds), vegetation, forestry and air quality. At the Tucumcari site, because of the involvement of state research and development funds and federal funds and the demonstration nature of the project, A-95 review was required. This review was also required because the met tower site was to be the future turbine demonstration site. The completion of the EA by DOE, including an archeological site survey, was necessary to satisfy the A-95 review requirement imposed by the New Mexico Historic Preservation Bureau. At the Goodnoe Hills site, for the towers and turbines, A-95 review was required because of the federal involvement (BPA and DOE) in the project. The review was conducted through the Washington State Historic Preservation Office. 


\section{Local Requirements}

Most of the regulatory requirements for the large wind turbines of the DOE Candidate Site Program occur at the federal and state levels due to the DOE sponsorship and the large size of the WECS installations. Generally, local requirements are more of a concern to small WECS operators. However, there are a number of local regulatory procedures about which developers of large WECS must be cognizant when trying to develop a WECS facility.

The basic local permit identified most frequently by the candidate sites is a city, town, or county building permit. Such a permit is required for any type of construction and is usually obtained in one to two weeks. With the exception of the Montauk Point site and the Cape Blanco site, all sites mentioning this requirement referred to it as an easy formality with which to comply. Officials at the Long Island Lighting Company indicated that approval of the town bui? ding permit for their proposed met tower will encompass approval by the town selectmen and compliance with the Wind Energy Conversion System Ordinance that the Town of East Hampton, New York is presently drafting. The Coos-Curry Electric Cooperative indicated that for a turbine to be built at the Cape Blanco site in Oregon, if that site were outside the exclusive farm use (EFU) zone, approval would be needed from the state Land Conservation and Development Commission due to an "enforcement order", i.e. a building moratorium, in the county. If the site is in the EFU zone a turbine is an approved use.

Another local permit of concern for turbine approval is an electrical permit. Few candidate sites mentioned this regulatory procedure because they plan to tie into their present power lines in the area of the 
turbine site. For non-utility wECS operators or for utilities that must install new power lines to turbine sites, an electrical permit from the local jurisdiction (city, town or county) may be required. In addition, for the construction of transmission lines, a county franchise permit may be required from the County Commission or County Utility Division for use of rights-of-way adjacent to county roadways.

Officials at the Bonneville Power Administration (BPA) mentioned a county road approach permit as a requirement from which they were not exempt from complying. This permit was required for the three Goodnoe Hills site roads to enter and connect onto the nearby county road. The fact that BPA was exempt from obtaining a conditional use permit from the Klickitat County Zoning Commission relates to the express powers of a federal agency which are deemed preemptive of local zoning control. Zoning compliance will be discussed further at the end of this section. While the goals of the federal Historic Sites, Buildings and Antiquities Act are generally administered through state historical commissions, a special case was presented with the Nantucket Electric Company's experience on Nantucket Island in Massachusetts. Approval of the local historical commission was one of the main regulatory constraints identified by the project applicants. The island of Nantucket does not receive any power from the mainland, as the island of Martha's Vineyard does, and it also feels a very strong commitment to historic preservation and conformance of new structures with old architectural styles. There is a potential area of conflict between the goals of historic preservation and the goals of developing alternate 
energy sources. However, so far this conflict has not materialized and the Nantucket historical commission has given prompt approval for met towers and small wind turbines to be erected on the island.

An additional state regulatory procedure that is carried out at the local level is the A-95 project review system established by the federal Office of Management and Budget. As discussed under State Requirements, the system seeks to identify at an early stage potential conflicts between federally assisted projects and state and local activities. The A-95 review also seeks to establish 1 ines of communication between the different levels of government and to foster coordinated plans and actions (NRDC, 1977:268). The agencies normally vested with clearinghouse review powers are regional planning commissions or councils of government (COGS).

An issue raised by several candidate sites (e.g., Goodnoe Hills, Nantucket, Montauk Point) and a principal barrier to the development of WECS in urban and suburban settings is the existence of zoning ordinances. Government control of the use one makes of private property has traditionally been justified on the basis of the protection of public health, safety, morals, and general welfare (including such issues as neighborhood character, economic development). The typical city or county zoning ordinance usually consists of a delineation of districts with lists of compatible permitted uses, and conditional or special uses that require discretionary permits. In addition, each district will have bulk, height, minimum lot size, setback and other requirements designed to protect that particular community's perception of the public health, safety, morals, and general welfare (Wind Task Force Memo, 1980). 
It is in the residential and commercially zoned districts that wECS are likely to run up against the greatest conflict with zoning ordinances, and because of land and other siting requirements these conflicts are likely to be more of a problem for small WECS, not the large turbines. In an area with a zoning ordinance, the height of met towers and wind turbines will usually require a variance, conditional use, zone change, or other special administrative proceeding. If a community wishes to exclude WECS it can legally do so, but if a community wishes to permit or encourage WECS development, it can remove any hindrances through amendment of its zoning ordinances (Coit, 1979:171). In the course of investigating DOE Candidate Sites, a number of proposed zoning ordinance amendments were brought to our attention. Appendix 3 contains a preliminary list of the communities and contact people knowledgeable about zoning ordinance amendments governing WECS that this study was able to identify given its limited resources. The list is far from complete but gives interested readers a starting point from which to pursue further investigations. Also of note is the fact that the California Energy Commission is drafting a model county ordinance for small WECS (10-50 kWe machines) which should be available soon.

The reason that zoning became an issue at the local level for some candidate sites and not for others is preemption. A municipal utility may be exempt from zoning regulation, and WECS regulated by a state's public service commission or subject to a state power plant siting statute also may be able to circumvent the zoning scheme. In some cases federal utilities or developers may not be subject to zoning (Mayo, 1977:9). 
One final local requirement for met tower and turbine installation that appeared as a recurring theme during the investigation of DOE Candidate Sites is the obvious necessity for negotiation of contracts for sale, lease, or easements with private landowners. The method of land acquisition is entirely dependent upon the needs of the facility and the intended land uses of the WECS operator. Even though land acquisition does not really quality as a regulatory procedure, it can represent a significant siting constraint of a local nature. 


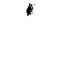




\section{Land Ownership}

In investigating the regulatory procedures undertaken by the DOE Candidate Sites for installation of met towers, it became apparent that one of the most important factors affecting regulatory requirements was land ownership. Whether a turbine site is on federal, state, town, or privately owned land makes a significant difference in terms of compliance with environmental legislation and regulations. This is not to understate the importance of other factors--such as utility ownership and project sponsorship--in determining how environmental review will be satisfied, but land ownership was mentioned more often by project developers as the key variable in the regulatory process.

Approximately one-third of the land in the U.S. is owned by the federal government and managed by federal agencies (NRDC, 1977:224). Most of this public land is managed by four agencies: the Forest Service of the U.S. Department of Agriculture, the Bureau of Land Mr nagement (BLM) of the U.S. Department of the Interior, the Fish and Wildlife Service of the U.S. Department of the Interior, and the National Park Service of the U.S. Department of the Interior. In addition, sizeable acreages are also administered by the various branches of the military. Eight out of twenty-one sites investigated in this study involve federal land and therefore are subject to different regulatory controls than sites on state, local, or privately owned land. While federal preemption allows for circumvention of some of the state and local permit requirements, the candidate site developers whose sites are on federal land mentioned the need to coordinate their activities with state and local officials in order to maintain good relations and a free exchange of environmental and other technical information. 
For the two sites on BLM land, Bridger Butte and Wells, the main regulatory requirements were a temporary use permit from the BLM and the environmental assessment prepared by the BLM for DOE in consultation with state and local officials. Because the Lincoln Ridge site is situated in the Green Mountain National Forest in Vermont and because of the additional federal involvement of the U.S. DOE through project sponsorship, it was determined that state land use controls (Vermont Act 250) did not have to be complied with. If the project sponsor, Green Mountain Power, decides to go ahead with the project on its own (without DOE sponsorship), a new issue will arise as to whether federal land ownership is sufficient to exempt the project from Act 250 and other local requirement compliance. Finally, the sites located on land owned by the military faced lengthy delays in trying to secure outgrant or lease agreements. In these cases, it took the resources of the U.S. DOE to speed the process of land acquisition.

For sites located in state parks (Montauk Point, Big Sable Point, and (ape $B$ lanco), the main regulatory constraint to siting of the met towers was a parks use permit. This is generally administered by the State Department of Natural Resources, which makes that department the lead agency for environmental review. The complexity and time requirements of this procedure varied widely with the impacts of the proposal as well as the intensity of park use and willingness of agency officials to approve new structures.

The two sites investigated that are located on town-owned 1 and, Nantucket and Provincetown, faced much more public scrutiny at the local level due to the stake each town had in the venture. Sites whose land is 
in private ownership simply followed a standard permitting process that normally consisted of FAA compliance at the federal level, state agency input to the DOE Environmental Assessment, and local building and conditional use permits. 
.

- 


\section{Wind Rights}

"Wind rights" has been defined as a term that describes "the acquisition, holding, and transferring of guaranteed access to the wind resource over land for electric power generation" (Noun et al., 1981:26). This may not be a present concern of participants in the DOE Candidate Site Program due to the utilization of predominantly undeveloped, rural locations for siting of met towers and turbines, and the scarcity of such installations. However, as rising fuel costs cause utilities and homeowners to compete more keenly for renewable sources of energy and as development encroaches upon the formerly undeveloped ridges and coastlines that are typically regarded as good wind resource areas, the lack of any legal doctrine assuring a WECS operator a guaranteed access to an unimpeded air flow could prove to be a significant constraint to wind turbine installation.

Oregon is the only state to currently have a law that protects "rights" to the wind. There, a law was recently passed (A-Engrossed Senate Bill 119) to prohibit restrictions on installation or use of wind energy systems, to provide for creation and termination of wind energy easements, and to authorize city or county planning commissions to recommend wind access ordinances. The law also provides for recordation, making wind energy easements and leases recordable documents. In such a manner constructive notice is provided to third parties.

However in most states, under current laws neighboring landowners to a WECS installation can construct, move, or build additions to structures and effectively diminish or deplete the WECS wind supply. A similar problem faces those who wish to install solar collectors. Because 
questions about solar and wind rights have only recently been identified as a legal concern, there is a definite lack of legal precedent or other authority from which to derive the acquisition of wind rights. An excellent discussion of the various strategies for acquiring and preserving a WECS developer's access to wind has been provided by the Oregon Attorney General's office (Wind Task Force Memo, 1980). These strategies can be divided into two groups: (1) private actions and (2) public actions.

\section{(1) Private Actions}

A. Fee Simple Acquisition to Sufficient Property Clearly, absolute ownership of enough surrounding property to guarantee sufficient wind in all significant energy-producing directions is the best solution to the problem of wind availability. This can prove prohibitively expensive, however. Another drawback to this approach is that acquisition of fee title to the entire tract of land where the WECS installation will be sited and to enough surrounding 1 and to ensure adequate wind flow should be made at the outset of the project's development. Only then will a WECS developer know whether or not there will be a problem with fee simple acquisition to the desired property. If a wind turbine is installed and subsequent sales of surrounding land result in wind flow impediment due to later development, there is nothing the turbine owner can do at that point if the problem neighbor does not wish to sell or negotiate some other type of cooperative agreement. 


\section{B. Lease of Surrounding Land}

Another possibility involves fee title acquisition to the land on which the WECS installation is situated and lease acquisition for sufficient surrounding property, or else lease acquisition to the entire project area. Long-term leases can be negotiated for the usable life of the WECS machine or for any desired time interval. Leases may be less costly than fee title acquisition but the lease holder is not gaining the investment value in terms of 1 and appreciation which accrues to the fee title owner. There may also be landlord-tenant conflicts over the duties each is expected to perform.

\section{Acquisition of a Negative Easement}

While owners and tenants are generally regarded as having possessory interests in property, the holder of an easement has only a privilege to make some special use of it. Through the acquisition of a negative appurtenant easement, the WECS owner can p rchase the legal right to prevent the adjoining landowner from obstructing wind flow. A negative appurtenant easement can be of perpetual or limited duration, and can be recorded as part of the property deeds to give notice of its existence to subsequent purchasers. Acquiring a negative appurtenant easement should normally be less expensive than obtaining fee title or a lease because there will still be permitted uses on the burdened land that do not interfere with wind flow. However, the use restrictions might possibly render the burdened property useless by precluding erection of residential structures within existing zoning and thereby cause the easement to be valued as high as outright purchase (Mayo et al., 1977:103). 


\section{Restrictive Covenants}

A covenant differs from an easement in that it is a promise respecting land rather than the grant of an interest in land. Covenants are a contractual device negotiated by private parties that are particularly appropriate to new residential or comnercial development. Restrictive covenants are commonly used to establish lot sizes, setback requirements, building design, management of common areas, and other such restrictions, and could easily be adopted (at least in theory) to the establishment of wind rights (Wind Task Force Memo, 1980).

\section{(2) Public Actions}

\section{A. Statutory Recognition of a Wind Access Easement}

The legislatures of several states have recently given statutory recognition to solar energy easements (examples cited in Noun, et al., 1981:27). While enactment of such legislation is not required for there to be legally binding solar easements, the existence of legislation sets policy and paves the way for other developments in the field. The Oregon solar energy easement statute goes one step further, and in section ORS 105.880 makes it impermissible for anyone transferring fee title to real property to prohibit the use of solar energy systems on that property (Wind Task Force Memo, 1980). It is important to note, however that this statute does not apply to wind energy. Similar statutes can be enacted to define wind rights and to authorize the establishment of wind access eas ements. 


\section{B. Wind Access Permits}

Another approach is for local jurisdictions to establish a permitting system for the acquisition of wind access rights. Once a permit is issued to a WECS operator, owners of adjoining property would be prohibited from using their property in ways that would interfere with the WECS (Wind Task Force Memo, 1980). If permits are issued prospectively for a desired installation to be erected at some future date, the permitting agency should require development of the WECS installation by a certain date in order to prevent speculators from tying up all the prime WECS locations (Wind Task Force Memo, 1980).

C. Public Acquisition of Wind Easements

If a state or local jurisdiction is particularly supportive of the development of wind power and other alternative energy sources, it would be possible for it to purchase wind access easements similar to those currently existing for conservation and scenic values preservation. These could then be leased to conservation agencies or WECS developers themselves.

\section{Zoning Techniques}

While zoning setback requirements for WECS found in zoning amendments are justified from a standpoint of safety and minimization of nuisance--like interferences, they also serve to protect wind rights. In some zoning ordinances, one finds setback distances of up to $71 / 2$ rotor diameters from downwind property lines (personal communication with Mr. Allen Friedman, California Energy Commission, 
September 18,1981$)$. Such requiremenets are aimed at making maximum utilization of wind resources in a commity, while protecting wind access for each individual WECS owner.

Other innovative land use devices which may be useful in promoting WECS energy are: transferable development rights, incentive zoning, floating zones, planned unit developments, and other "flexible" land use planning techniques to achieve specific goals. For the promotion of WECS development and preservation of wind access, communities can also build these policies into their land use plans and zoning ordinances (Wind Task Force Memo, 1980). The reader is referred to the section on local requirements for further zoning considerations.

\section{E. Eminent Domain}

A publicly regulated utility has eminent domain powers to acquire land for energy development (Noun et al., 1981:58). In theory, this power could apply to wind access areas (upwind rights) as well as to the property for the WECS installations themselves. The Bonneville Power Administration, a federal agency, used its eminent domain powers to acquire a portion of transmission line right-of-way easements for its Goodnoe Hills Project. A private utility has limited eminent domain powers. While it cannot conderan all the land it needs for a particular energy development, it can use eminent domain powers for transmission line right-of-way acquisition. States seeking to promote the use of wind power could grant more eminent domain powers to utilities so that they do not become thwarted by an uncooperative landowner in their efforts to develop a good WECS site (Noun et al., 1981:58). 


\section{Public Attitudes}

It is of great interest to many participants and observers in the wind energy field how the public has reacted and will react to large turbines, particularly to clusters of 25,50 or more machines (Noun et al., 1981:28). For most large turbines or turbine proposals to date there has been little opposition, with one exception noted below. For smaller turbines in more densely populated areas there has been a more consistent showing of public concerns for such issues as safety, noise, visual impact and electromagnetic interference.

Almost all the candidate sites evoked a positive response from the public at the time of the siting of the met towers. At some sites newspaper articles favorably describing the project were written (for example, Finley, North Dakota) and at many sites community support was a motivating factor in the utility's decision to become involved in the project (for example, Nantucket, Mass.).

At one site, however, the siting of the meteorological tower met with significant public opposition. The Lincoln Ridge proposal (originally a site proposed by the Green Mountain Power Company as part of the candidate site program) generated substantial public opposition over erection of the tower. A community group called Save the Lincoln Mountain Committee formed early in the process of siting the met tower because they were "aesthetically disturbed by the notion of a 'massive' wind turbine on 'their' mountain" (Sheperdson, 1980:11). The committee grew into a we11-organized, community effort that was backed by the town of Lincoln's Board of Selectmen and Sugarbush Valley, Inc. on the other side of the mountain. Opposition centered on several points including 
the fact that the community felt the met tower and turbine should not have been separated in the environmental assessment process and that the ridge was technically not a good site for a turbine because of problems such as icing and fog. The committee was also opposed, at a more general level, to the siting of a turbine on such a picturesque ridge in Vermont and felt that there would be problems with access, an adequate safety zone and a possible conflict with a U.S. Forest Service designation of the area as Management Area III (which precludes the construction of power-generating equipment) (Anderson, 1981). A public hearing was held where opponents to the project registered their opposition, and in April of 1981 the Committee moved to file suit in federal district court, "requesting a judicial writ forcing the U.S. DOE and the U.S. Forest Service to assess the environmental impact of a large-scale wind turbine on the mountain" (Gillmor, 1981a). In that same month DOE decided to drop the Lincoln Ridge site from its program, due to severe funding cutbacks proposed by President Reagan in the overall wind energy program. The Green Mountain Power Company has since decided to reapply to the Forest Service for permission to install a 50-foot met tower on top of Lincoln Mountain, and opponents of the original proposal plan to fight the new one (Gillmor, 1981b). No other project in the candidate site program has met with opposition as organized and severe as that at Lincoln Ridge, probably indicating the very site-specific nature of the opposition. That is, the Lincoln Ridge group is not opposed to wind technology itself but to the particular site and to the (original) lack of public involvement in the siting process. 
An example of a large-scale public involvement program eliciting public concerns early in the siting process is the San Gorgonio Pass Wind Program, administered by the Bureau of Land Management and Riverside County. There, the public is being asked to help identify important issues as part of the scoping process for an EIS/EIR which must be prepared by the BLM and the county for a large area in the Pass. Two public hearings have been held to date, generating lists of public concerns. These concerns include: noise, ground vibration, television interference, aesthetic effects, public safety, and well being of endangered species of plants and animals. Property values, tourism, rights of individuals, transmission lines and other accompanying facilities also surfaced as concerns (U.S. Dept. of Interior and Riverside County, 1981).

And, as noted in the report on the public involvement program, Underlying both meetings were two concerns, expressed by many of those present. . . many private citizens seemed anxious to preserve their right to construct individual, or "mom and pop" generating facilities for their own use on private property, or perhaps to produce power for sale to utilities. The same feelings were expressed regarding safeguards against allowing large corporations to gain control of the resource, and to assure that all interested parties be given an opportunity to use the public lands for this purpose on a fair basis. Delays in granting permits for constructing, testing or operating wind generating units for small one family units was a concern heard frequently (U.S. Department of Interior and Riverside County, 1981:7).

Public concerns regarding smaller scale WECS also center on the types of issues identified in the BLM/County of Riverside involvement process, with aesthetics and noise being primary concerns. Partly in response to some of these concerns several localities have passed or are considering passage of ordinances governing the siting of WECS (see Appendix 3 ). According to one official the Lincoln, Nebraska ordinance, for example, 
can be considered very restrictive, basically because people do not want to see WECS in a residential environment. A minimum two-acre lot is required to satisfy all the restrictions.

Another example that surfaced in our discussions with candidate site officials of a town where public concerns for WECS received much publicity is Hanover, New Hampshire. There, a private citizen requested permission to erect a windmill on his ridge property, interfering with many neighbors' views. His request was denied. The Planning Board tried to draw up an amendment to their zoning ordinance to cover small WECS but found that no one could agree on what should be in such an ordinance. People in the wind energy business discouraged Hanover from writing such an amendment for fear that it might stifle efforts in the Northeast to promote wind energy utilization. The Planning Board thus decided to wait one year before taking any action. Currently WECS are not allowed in town, but in July of 1981 the Board received another request for installation of such a system. An official in the town felt that this latest request would not face public opposition and should receive approval from the Zoning Board of Adjustment.

Thus public attitudes toward WECS appear to be at least somewhat dependent on site-specific characteristics. Also, Noun et al. point out that the public has many misconceptions about wind machines and is largely uninformed about WECS (1981:29). Both these points argue strongly for the need for a utility and/or developer to involve the commity early and continuously in the siting process. 
Anderson, Lester. 1981. "There is More to Wind Power than Wind." Vermont Environmental Report. May/June.

Coit, Lynde. June 1979. Wind Energy: Legal Issues and Institutional Barriers. Golden, Colorado: Solar Energy Research Institute.

Gillmor, Dan. 1981a. "Lawsuit, Budget Cuts Threaten Wind Project." The Valley Voice. April 7.

Gillmor, Dan. 1981b. "GMP Applies for Wind Towers." The Valley Voice. May 26.

Mayo, Louis H. et a1. 1977. Legal-Institutional Implications of Wind Energy Conversion Systems NSF/RA-770204. Washington, DC: The George Washington University for the National Science Foundation, RANN.

Natural Resources Defense Council, Inc. (NRDC). 1977. Land Use Controls in the United States. New York: The Dial Press/James Wade.

Noun, Robert J.; Michael Lotker and H. Paul Friesema. 1981. Utility Siting of WECS: A Preliminary Legal/Regulatory Assessment. SERI/TR-744-778. Golden: Solar Energy Research Institute.

Oregon Attorney General's Office. May 21, 1980. Legal Issues Surrounding Wind Energy Conversion Systems. Memorandum to the Wind Task Force [cited as Wind Task Force Memo].

Sheperdson, William. 1980. "Lincoln's Wind Storm." The Vermont Vanguard Press. Vo1. III, No. 32. September 16.

U.S. Department of Energy, Wind Systems Branch. 1980. Environmental Evaluation: Candidate Sites for Government Installed Wind Measuring Equipment. Washington, DC: U.S. DOE Wind Systems Branch.

U.S. Department of the Interior, Bureau of Land Management and Riverside County. 1981. San Gorgonio Pass Wind Program: A Report on Public Involvement in Identification of the Issues. May. 
Appendix I:

Contacts 
Appendix 1: Contacts

I. Candidate Site Contacts

1. Big Sable Point, Michigan

Mr. Ed Browning

Staff Engineer

Consumers Power Company

1945 W. Parnall Road

Jackson, MI 49201

(517) 788-2205

Mr. Tom O'Masta

Senior Engineer (Air Quality Specialist)

Consumers Power Company

Jackson, Michigan

(517) 788-1934

2. Bridger Butte, Hyoming

Mr. Anton Tonc or Mr. Craig V. Meacham Intermountain Consumer Power Association 8722 South 300 West

Sandy, Utah 84070

(801) $566-9101$

3. Cape Blanco, Oregon

Mr. Bob Drake

Port Orford District Manager

Coos-Curry Electric Cooperative, Inc.

P.0. Box 460

Port Orford, OR 97423

(503) $332-2241$

4. Diablo Dam, Washington

Mr. Al Yamagiwa

Engineering Manager

Energy Resources Division

Seattle City Light

1015 Third Avenue

Seattle, Washington 98104

(206) 625-3804

5. Finley, North Dakota

Mr. Merle Holden

Project Manager

Sheyenne Valley Electric Cooperative, Inc.

Finley, ND 58107

(701) $524-1110$ 
Mr. Lynn Fundingsland (now at Morehead Planning Office:

(formerly) Energy Coordinator

(218) 299-5370

Lake Agassiz Regional Council

Suite 205, South Plaza

1621 S. University Drive

Fargo, North Dakota 58103

(701) 235-7885

6. Fort Sil1, Oklahoma

Mr. E. J. Babineaux

Engineering Technician

Environmental Division

Facilities Engineering

Building 1950

ATZR-FEEO

Fort Sill, Oklahoma 73503

(405) 351-2715

7. Goodnoe Hills, Washington

Mr. Ron Holeman, General Engineer or

Mr. Nick Butler, Electrical Engineer

Bonneville Power Administration

P.O. Box 3621

Portland, OR 97208

(503) 234-3361, ext. 4524

Mr. Don Munro

Land Acquisition Department

Bonneville Power Administration

Portland, Oregon

(503) 234-3361, ext. 4677

Mr. Richard Axell or Mr. Gordon Davisson, Engineer

Project Manager

Boeing Company

Seatt1e, WA 98124

(206) 575-5959

8. Huron, South Dakota

Mr. Jeff Nelson

East River Electric Power Co-Op, Inc.

Madison, SD 57042

(605) 256-4536 
9. Ilio Point, Hawaii

Mr. John H. Urauchi

Superintendent of Administration

Molokai Electric Co., Ltd.

P.0. Box 378

Kaunakakai, Molokai

Hawai i 96748

(808) $553-3234$

10. Kahua Ranch, Hawaii

Mr. Chip Higgins

Director of Energy Supply

Hawaii Electric Light Company, Inc.

P.0. Box 2750

Hilo, HI 96720

(808) 548-7721

Mr. D. Richard Neill

Energy Self-Sufficiency Coordinator

Hawai Natural Energy Institute

University of Hawaii at Manoa

Honolulu, Hawaii 96822

(808) $948-8788$

11. Livingston, Montana

Mr. Leonard Decco

or

Resources Planning Engineer

Montana Power Company

40 East Broadway

Butte, Montana 59701

(406) 723-5421

12. Meade, Kansas

Mr. Douglas Fisher

Super intendent

City Hall

132 So. Fowler

Meade, Kansas 67864

(316) 873-2012

13. Minot Radar, North Dakota

Mr. Lars Nygren

Manager, Minot Office

Verendrye Electric Cooperative, Inc.

Minot, North Dakota 58701

(701) 852-0406
Mr. Peter Atonioli, Engineer

Alternative Energy

Division 
14. Montauk Point, New York

Mr. Bruce Humenik

Chief Engineer

Long Is land Lighting Company

175 East old Country Road

Hicksville, New York 11801

(516) 733-4085

Ms. Eileen Fairfield

Environmental Scientist

Environmental Engineering Department

Long Is land Lighting Company

(516) 733-4752

15. Nantucket, Massachusetts

Ms. Linda Holland

Nantucket Wind Energy Council

Nantucket, Massachusetts 02554

(617) 257-9994

16. Pacheco Pass, California

Mr. Robin Reynolds

California State Department of Water Resources

Sacramento, California

(916) 322-6858

17. Provincetown, Massachusetts

Mr. Robert Tegelaar

Director of Research \& Development

New Bedford Gas \& Edison Light Co.

P.0. Box 190

Cambridge, MA 02139

(617) $864-3100$

18. San Augustin Pass, New Mexico

$\mathrm{Mr}$. James Brown

Director, Resource and Analysis

E1 Paso Electric Company

P.O. Box 982

E1 Paso, Texas 79960

(915) 543-5816 
19. Stratton Mountain, Vermont

Mr. John Bohn

Chief Engineer

Vermont Electric Cooperative, Inc.

School Street

Johnson, Vermont 05656

(802) 635-2331

20. Tucumcari, New Mexico

Mr. Hugh Riley, Director

City of Tucumcari

Municipal Power Company

P.0. Box 1188

Tucumcari, NM 88401

(505) 461-2145

21. Wells, Nevada

Mr. Lee Standley

Operations Manager

Wells Rural Electric Company

P.0. Box 365

Wells, Nevada 89835

(702) 752-3328 
Appendix 1: Contacts

II. Regulatory Contacts

California

Mr. Robert Thomas or Mr. Allen Friedman

California Energy Commission

1111 Howe Avenue

Sacramento, California 95825

(916) 920-6051

\section{Hawaii}

Ms. Helene Takemoto

Office of Environmental Quality Control

Office of the Governor

550 Halekauwila Street

Room 301

Honolulu, Hawaii 96813

(808) 548-6915

\section{Kansas}

Mr. David Martin

Manager, Solar and Wind Program

Kansas Energy Office

Topeka, KS 66612

(913) 296-2496

\section{Massachusetts}

Mr. Samuel Mygatt

Executive Director of the Environmental Impact Review Section

Massachusetts Executive office of

Environmental Affairs

100 Cambridge Street

Boston, Massachusetts 02202

(617) 727-5830

Michigan

Mr. William Turney

Deputy Director

Michigan Department of Natural Resources

Stevens T. Mason Building

Box 30028

Lansing, Michigan 48909

(517) 373-2425 


\section{Montana}

Ms. Deborah B. Schmidt, Director

Montana Environmental Quality Control

Capitol Station

Helena, Montana 59601

(406) 449-3742

Mr. Randall Moy

Major Facility Siting Division

Department of Natural Resources

32 s. Ewing

Helena, Montana 59601

(406) 449-3712

Nebraska

Mr. Jeff Morgan

Nebraska Energy Office

Craft State Office Building

200 S. Silber

N. Platte, Nebraska 69101

(308) $534-6780$

\section{Nevada}

Mr. David Vandenberg

Real Estate Specialist and Permit Coordinator

Bureau of Land Management

E1ko, Nevada 89801

(702) 738-4071

Mr. Bob Loux

State Department of Energy

Carson City, NV 89701

(702) 885-5157

New Hampshire

Mr. John Cutting

Director, Wind Energy Program

Governor's Council on Energy

$21 / 2$ Beacon Street

Concord, New Hampshire 03301

(603) 271-2711 
New Mexico

Dr. Gerald Leigh

Senior Technical Advisor

New Mexico Engineering Research Institute

University of New Mexico

P.0. Box 25, Campus Post Office

Albuquerque, New Mexico 87131

(505) 844-6187

Mr. Ken Barnett

New Mexico Solar Energy Institute

Box 3E1

Las Cruces, New Mexico 88003

(505) 646-1846

New York

Dr. Rudolph Wiley

Project Manager, Wind Energy Development

Energy Research and Development Office

Albany, New York

(518) 465-6251, ext. 252

North Dakota

Mr. August Keller

Director, Energy Impact office

Bismarck, ND 58505

(701) 224-3188

Oregon

$\mathrm{Mr}$. Don Bain

Oregon State Energy Office

102 Labor and Industries Bullding

Salem, OR 97310

(503) $378-4040$

Rhode Is land

Mr. Robert Ericson

Coordinator, Solar Resources

Governor's Energy office

80 Dean Street

Providence, Rhode Island 02903

(401) 277-3370 


\section{South Dakota}

Mr. Steven Perner

South Dakota Department of

Environmental Protection

Pierre, South Dakota 57501

(605) 773-3351

Vermont

Mr. Richard Cowart

Executive Director, Vermont

Environmental Board

Montpelier, Vermont 05602

(802) 828-3309

Washington

Mr. Ray Anderson

Washington Energy Office

$400 \mathrm{E}$. Union

Olympia, Washington 98504

(206) 754-0700

\section{Wyoming}

Mr. Ed Maycumber

Assistant Director

Wyoming Energy Conservation Office

Capitol Hall Building

25 th and Pioneer

Cheyenne, Wyoming 82002

(307) 777-7131 
Appendix 2:

Oregon Standards for the Siting of Wind Energy Facilities 
-

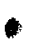




\section{Department of Energy}

LABOR \& INDUSTRIES BUILDING, ROOM 102, SALEM, OREGON 97310 PHONE 378-4040

August 12, 1980

WIND SITING RULES ENACTEO!

On August eighth Oregon's Energy Facility Siting Council (EFSC) formally approved the rules for obtaining site development permits for wind facilities. The EFSC is a one-stop permitting authority whose permits are binding on, but may be made subject to, the requirements of all state and local parties to the permitting process. All WECS 'farms' of 25 MW and larger will be required to obtain a pernit from the EFSC. Facilities of less than $25 \mathrm{MW}$ must obtain their site development permits separately and individually from all applicable state and local authorities.

For more information contact:

$$
\begin{array}{ll}
\text { Peter Paquet, Siting staff } & \text { (503) 378-6916 } \\
\text { Don Bain, Wind Specialist } & \text { (503) 378-6715 }
\end{array}
$$


Standards for the siting of

Wind Energy Facilities

Rule 345-115-010 - Purpose:

The purpose of these rules is to establish standards that applicants for site certificates for wind energy facilities must meet. The Council will apply these standards in reaching a decision for or against issuance of a site certificate for the construction and operation of a wind energy facilitiy and its "related and supporting facilities", as defined in ORS $469.300(10)$ and (13), respectively. The same standards will be applied by the Council in deciding whether an existing site certificate should be amended to the extent and in the manner amendment is authorized by the site certificate. When the Council deems appropriate, it will adopt additional standards. Any additional standards will be adopted sufficiently in advance of the close of testimony at a hearing on a site certificate to allow parties to address the rule, or if after the close of testimony, in sufficient time to allow the parties an opportunity to supplement their testimony to of fer evidence relating to the new rule.

Rule 345-115-012 - Applicability:

These standards are applicable to site certificate applications for all wind energy facilities rated at 25 megawatts or greater. 
Rule 345-115-015 - Interpretation:

These standards are authorized under ORS $469.470(3)$ and shall be interpreted so as to carry out the purposes of ORS 469.300 through $469.570,469.990$ and 469.992 governing energy facility siting in Oregon. The fundamental policy of that law is set out in ORS 469.310 .

Rule 345-115-020 - Definitions:

1. The definitions set out in ORS 469.300 are hereby incorporated as the definitions to be used in interpreting these standards, unless a term is specifically defined within these standards.

2. A "wind energy" facility means all wind turbines or other such devices, owned by a person, which produce electric power from wind, and are:

(a) connected to a common switching station, or

(b) constructed, maintained, or operated as a contiguous group of devices.

3. "Related or supporting facilities" means structures or equipment adjacent to and associated with a wind energy facility and shall include but is not limited to transmission line towers and substations.

4. "Facility" means the wind energy facility and its related or supporting facilities.

Ruie $345-115-030$ - Standards Relating to Public Health and Safety:

In order to issue a site certificate for a wind energy facility the Council must find that:

1. To the extent feasible, the facility will be designed to satisfy the Department of Environmental Quality's octave bands 1 imitations set forth in OAR $340-35-035(1)(f)$ in effect as of the ef fective date of these standards.

2. The proposed facility will be designed to exclude members of the public from close proximity to the turbine blades and electrical equipment. 
3. The facility will be designed to preclude, to the greatest extent feasible, structural fallure of the tower or blades which could endanger the public safety; and that adequate safety devices and testing procedures designed to warn of impending fallure or to minimize the consequencs of such failure will be employed by the applicant.

Rule 345-115-040 - Environmental Impact:

In order tọ issue a site certificate for a wind energy facility the Council must find that:

1. The proposed site of the facility is not in one of the designated natural resource areas 1 isted below and the proposed project is not likely to produce significant adverse impacts on any such area including:

(a) National Parks, National Monuments and National Wildlife Refuges;

(b) State of Oregon Parks, Waysides, Wildlife Refuges and Natural Area Preserves;

(c) Wilderness areas as established under the Federal Wilderness Act (16 USC 1131 et seq.) and areas recommended for designation as wilderness areas pursuant to Section 603 of the Federal Land Policy and Management Act of 1976 (P.L. 94-579);

(d) Scenic Waterways designated pursuant to ORS 390.825;

(e) Federally-designated Wild and Scenic Rivers established pursuant to P.L. 90-452;

(f) Experimental areas established by the Rangeland Resources Program, School of Agriculture, Oregon State University;

(g) Areas having unique or significant wildlife, geologic, historic, botanical, research or recreational values as lawfully designated by the state agency having jurisdiction over such values.

2. Studies have been performed characterizing the relative abundance and diversity of the plant and animal species at the proposed site of the facility. (Shannon-Weaver index $H^{\prime}$ shall be a satisfactory measure of diversity) and 
(a) The proposed is not likely to jeopardize the continued use of deer, elk and antelope wintering ranges or migration routes.

(b) The above ground portions of the proposed facility shall not be located on antelope fawning areas, sage grouse strutting and nesting areas or water fowl nesting and rearing areas which are necessary to sustain the existing local or migratory populations of such species.

(c). areas within the boundary of the facility site with unstable or fragile soils have been satisfactorily identified and available construction techniques $c$ an be employed to reduce adverse impacts such as erosion and compaction.

(d) The bird species within the area af fected by the proposed facility have been identified and the facility is not likely to jeopardize the continued existence of local or migratory populations of such bird species.

(e) Construction and operation of the facility is not likely to jeopardize the continued existence of any of the following species, or destroy habitat critical to continued existence of these species.

i. Wildife

(A) Deer, Columbian white-täiled (Odocoileus virginianus luecurus),

(B) Wolf, Gray (Canus lupus),

(C) Eagle, Bald (Hailiaestus leucocephalus),

(D) Falcon, American peregrin (Falco peregrinus anatum),

(E) Falcon, Arctic peregrin (Falco peregrinus tundrius),

(F) Goose, Aleutian Canada Branta canadensis leucopareia),

(G) Pelican, brown (Pelecanus occidental is),

(H) Butterily, Oregon silverspot (Speyeria zerene hippolyta), 
ii. Plants - any of the fifty-one species proposed by the Fish and Wildlife Service as endangered in Oregon by publication in the Federal Register (41 FR 24524; June 16, 1976).

NOTE: The species identified in subsection (e) consist of endangered and threatened wildlife listed as of October 1, 1978, in 50 CFR Part 17 with a range which includes Oregon, and species in Oregon proposed by the Fish and Wildlife Service for addition to the list in 50 CFR Part 17 as published in the Federal Register.

3. The proposed facility can be designed to reduce its interference with radio, television and microwave signals to the lowest practicable level; and the operator of the proposed facility agrees to restore reception of radio, television and microwave signals to the levels present prior to operation of the proposed facility, at no cost to those experiencing interference resulting from the proposed facility.

Rule 345-115-045 - Land Use:

In order to issue a site certificate for a wind energy facility the Council must find that:

1. The Land Conservation and Development Commission has acknowledged, pursuant to ORS 197.251 (1979 replacement part), the comprehensive land use $p l a n(s)$ and implementing measures of the general purpose local government( $s$ ) having land use planning jurisdiction over the site of the facility; and that the facility has been determined by the local government(s) to be consistent with the plan(s) and measures.

2. That if the $p l$ an and implementing measures have not been acknowledged by the Land Conservation and Development Commission, the applicant has demonstrated to the Council that after providing notice and opportunity for public and other government agency review and comment, the statewide planning goals (OAR Chapter 660, Division 15) have been considered and applied by the local government(s) during a land use review of the facility and such facility has been determined by the local government(s) to be consistent with applicable statewide planning goals and local land use $\mathrm{plan}(\mathrm{s})$ and measures. 
3. That if the local government(s) having land use planning jurisdiction over the site of the facility has not completed a land use review of the facility prior to approval of a site certificate as required by subsection (1) and (2) of this rule, or if such local government has denied that the facility is consistent with applicable statewide planning goals and land use plans and measures the Council has determined that the application is consistent with the statewide planning goals and land use ordinances. Provided, however, that a site certificate authorizing the construction within the boundaries of an incorporated city shall be conditioned on compliance with city ordinances in effect on the date of the application of the site certificate as required by ORS $469.400(6)$.

Rule 345-115-050 - Socioeconomic Impacts:

In order to issue a site certificate for a wind energy facility the Council must find:

1. The applicant has identified the major and reasonably foreseezble socio-economic impacts on individuals and communities located in the vicinity of the facility resulting from construction and operation, including, but not limited to, anticipated need for increased governmental services or capital expenditures, and

2. The applicant and the affected local government have reached agreement to provide adequate resources to mitigate the impacts identified pursuant to (1), and

3. the applicant has an adequate process for periodically updating, during construction and operation, its assessment of anticipated impacts of the facility.

Rule 345-115-051 - Historic and Archeaological Sites

In order to issue a site certificate for a wind energy facility the Council must find that the proposed facility is not likely to cause significant adverse impacts within historic sites or upon archaeological resources. 
Rule 345-115-052 - Standard Relating to Water Rights

In order for the Council to issue a site certificate for a wind energy factlity the Council must find that the requirements for water used in construction and operation of the facility can be met without infringing upon the existing water rights of other persons.

Rule 345-115-053 - Organization, Managerial and Technical Expertise

In order for the Council to issue a site certificate for a wind energy facility the Council must find that the applicant has the organization, managerial, and technical expertise to construct, operate, and retire the facility. To this end, the applicant shall present evidence relating to:

1. The applicant's previous experience, if any, in constructing, operating, and retiring similar facilities;

2. The qualifications of the applicant's personnel who will be responsible for constructing, operating and retiring the facility; and

3. The qualifications of any architect-engineer, major component vendor, or prime contractor upon whom the applicant will rely in constructing, operating, and retiring the facility.

Rule 345-115-054 - Financial Assurance

In order to issue a site certificate for a wind energy facility the Council must find that the applicant, together with all co-owners, possesses or has reasonable assurance of obtaining the funds necessary to cover estimated construction costs, operating costs for the design lifetime of the facility, including, but not limited to, related fuel cycle costs, and the estimated costs of retiring the facility. 


\section{Rule 345-115-055 - Applications}

1. The applicant shall submit an application which includes, but is not limited to:

(a) description of the facility;

(b) description of the site and its existing environment.

(c) description of construction and operation of the facility with their attendant impacts;

(d) description of proposed techniques for monitoring facility impacts;

(e) description of any required deconmissioning or waste disposal sites and methods;

(f) approvals required from governmental agencies; and

(g) a proposed site certificate.

PP:sir

$6092 \mathrm{~A}$

$8 / 1 / 80$ 


\section{,}


Appendix 3:

Local Wind Energy Ordinances 


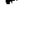


Preliminary Listing of Communities with Enacted or Proposed Zoning Ordinance Amendments Governing WECS*

\section{Community}

1. East Hampton, New York

2. Fairfield, California

Proposed

Enacted

5. Lincoln, Nebraska

6. Lower Township, New Jersey

7. North Platte, Nebraska
Enacted

Enacted or

Proposed

Proposed

Enacted
Proposed

Dr. Walter Eaton

Chairman, Hanover Planning Board Town Hall

Hanover, N.H. 03755

(603) 643-4000, ext. 3556

Mr. Michael DeKalb

Lincoln City-Lancaster County

Planning Department

555 South 10 th Street

Lincoln, Nebraska 68508

(402) 473-6493

Mr. Joe Zahora

Lower Township, New Jersey

Mr. Jeff Morgan

Nebraska Energy office

Craft State Office Building 200 S. Silber

North Platte, Nebraska 69101 (308) $534-6780$

\footnotetext{
* These ordinances represent only those that surfaced during our communications with individuals regarding the Candidate Site program. It is not intended to be a comprehensive list but rather a starting point from which readers may pursue further investigations.
} 
8. Old Lyme, Connecticut

9. Spokane County, Washington
Enacted

Proposed
Mr. Ed Mehan

Connecticut River Estuary Regional Planning Agency Westbrook Road

Essex, Connecticut 06426

(203) 670-0944

Mr. Thomas G. Mosher

Special Programs Administrator Spokane County Planning Dept.

Broadway Centre Building

N. 721 Jefferson Street

Spokane, Washington 99260

(509) 456-2205

Pacific Gas \& Electric Co. or Cal. Energy Commission

12. Wichita,

Kansas 


\section{DISTRIBUTION}

No. of

Copies

\section{OFFSITE}

A. A. Churm

DOE Patent Division

9800 S. Cass Avenue

Argonne, II 60439

Dan F. Ancona

Department of Energy

Wind Energy Technology Division

1000 Independence Avenue

Forrestal Building, Room 5F059

Washington, DC 20585

Carl I. Aspliden

Battelle Memorial Institute

Washington Operations office

2030 M street, N.W.

Washington, DC 20036

Louis V. Divone

Department of Energy

Wind Energy Technology Division

1000 Independence Avenue

Forrestal Building, Room 5F059

washington, DC 20585

George P. Tennyson

Department of Energy

Albuquerque Operations office

P.O. Box 5400

Albuquerque, NM 87110

27 DOE Technical Information Center

Dale R. Bervig

10235 Oakmont Circle

Lenexa, KS 66215

Richard Axell, Project Manager

Boeing Company

Seattle, WA 98124
No. of

Copies
Ron Holeman

Bonneville Power Administration

P.C. Box 3621

Portland, OR 97208

Doug Seely

Bonneville Power Administration

P.O. Box 3621

Portland, OR 97208

G. Haldane Bradshaw, Manager

Bridger Valley Electric Association

Mountain View, WY 82939

David Vandenberg

Real Estate Specialist and

Permit Coordinator

Bureau of Iand Management

Elko, NV 89801

Robert Thomas

California Energy Commission

1111 Howe Avenue

Sacramento, CA 95825

Michael Elliott

$\mathrm{CH} 2 \mathrm{M}-\mathrm{Hill}$

700 Clearwater Lane

P.O. Box 8748

Boise, ID 83706

Douglas Fisher

Superintendent, City Hall

132 South Fowler

Meade, KS 67864

Ed Browning

Consumers Power Company

1945 W. Parnall Road

Jackson, MI 49201 
No. of Copies

Tom O'Masta

Consumers Power Company

1945 W. Parnall Road

Jackson, MI 49201

Bob Drake

Port Orford District Manager

Coos-Curry Electric Cooperative, Inc.

P.O. Box 460

Port Orford, OR 97423

Randall Moy

Major Facility Siting Division

Department of Natural Resources

32 South Ewing

Helena, MT 59601

R. Thomas Segall

Geological Survey Division

Department of Natural Resources

P.O. Box 30028

Lansing, MI 48909

Robin Reynolds

Department of Water Resources

P.O. Box 388

Sacramento, CA 95802

John DeGlow

Department of Water Resources

P.O. Box 388

Sacramento, CA 95802

Jeffrey Nelson

East River Electric Power Co-Op, Inc.

Madison, SD 57042

James Brown

Director, Resource and Analysis

El Paso Electric Company

P.O. Box 982

El Paso, TX 79960

August Keller

Director, Energy Impact office

Bismarck, ND 58505
No. of

Copies

Rudolph wiley

Project Manager, Wind Energy Dev.

Energy Research \& Development Office

Albany, NY

E. J. Babineaux

Facilities Engineering

Building 1950, ATZR-FEEO

Fort Sill, OK 73503

John Cutting

Director, Wind Energy Program

Governor's Council on Energy

$21 / 2$ Beacon Street

Concord, NH 03301

Robert Ericson

Coordinator, Solar Resources

Governor's Energy Office

80 Dean Street

Providence, RI 02903

E. Chipman Higgins

Director of Energy Supply

Hawaii Electric Light Company, Inc.

P.O. Box 2750

Hilo, HI 96720

Fred Johnson

Director of Energy Supply

Hawaii Electric Light Company, Inc. P.O. Box 2750

Hilo, HI 96720

Anton Tonc

Intermountain Consumer Power Assoc. 8722 South 300 West

Sandy, UT 84070

Craig V. Meacham

Intermountain Consumer Power Assoc.

8722 South 300 west

Sandy, UT 84070

Monte Richards

Kahua Ranch, P.O. Box 837

Kamuela, HI 96743 
No. of

Copies

David Martin

Manager, Solar and Wind Program

Kansas Energy office

Topeka, KS 66612

Eileen Fairfield

Environmental Engineering Department

Long Island Lighting Company

175 East old Country Road

Hicksville, NY 11801

Bruce Humenik

Iong Island Lighting Company

175 East old Country Road

Hicksville, NY 11801

Andrew Matura

Long Island Lighting Company

175 East old Country Road

Hicksville, NY 11801

Samuel Mygatt

Massachusetts Executive office of Environmental Affairs

100 Cambridge Street

Boston, MA 02202

William Turney, Deputy Director

Michigan Department of Natural

Resources

Stevens T. Mason Building

Box 30028

Lansing, MI 48909

John H. Urauchi

Superintendent of Administration

Molokai Electric Co., Ltd.

P.O. Box 378

Kaunakakai, Molokai, HI 96748

Paul Laird

The Montana Energy and MHD Research

\& Development Institute

P.O. BoX 3809

Butte, MT 59701
No. of

Copies

Deborah B. Schmidt, Director

Montana Environmental Quality

Control

Capitol station

Helena, MT 59601

Leonard Decco

Montana Power Company

40 East Broadway

Butte, MT 59701

Hugh Riley, Director

City of Tucumcari

Municipal Power Company

P.O. Box 1188

Tucumcari, NM 88401

Rick Rickard, President

Nantucket Electric Company

Fairgrounds Road, P.O. Box 179

Nantucket, MA 02554

Linda Holland

Nantucket Wind Energy Council

Nantucket, MA 02554

Jeff Morgan

Nebraska Energy Office

Craft state Office Building

200 South Silber

North Platte, NB 69101

Robert Tagelaar

Director of Research \& Development New Bedford Gas \& Edison Light Co. P.O. Box 190

Cambridge, MA 02139

Ken Barnett

New Mexico Solar Energy Institute P.O. Box 350L

Las Cruces, NM 88003

John C. Baiardi, Director

New York Ocean Science Laboratory Montauk, NY 11954 
Helene Takemoto

Office of Environmental Quality Control

550 Halekauwila street

Honolulu, HI 96813

Don Bain

Oregon State Energy office

102 Labor and Industries Building

Salem, OR 97310

John wade

Department of Atmospheric Sciences

Oregon State University

Corvallis, OR 97331

Alan T. Yamagiwa, Engineering Manager

Energy Resources Division

Seattle City Light

1015 Third Avenue

seattle, WA 98104

Merle Holden, Project Manager

Sheyenne Valley Electric Co-Op., Inc.

Finley, ND 58107

Boh Noun

So ar Energy Research Institute

1617 Cole Boulevard

Golden, CO 80401

Steven Perner

South Dakota Department of

Environmental Protection

Pierre, SD 57501

Bob Loux

State Department of Energy

Carson City, NV 89701

W. R. Thorn, Manager

Wind Systems Engineering

TERA Corporation

2150 Shattuck Avenue

Berkeley, CA 94704
Anders Daniels

Department of Meteorology

University of Hawaii at Manoa

Honolulu, HI 96822

D. Richard Neill

Hawaii Natural Energy Institute University of Hawaii at Manoa

Honolulu, HI 96822

Eugene N. Frey

New Mexico Engineering Research Institute

The University of New Mexico

Albuquerque, NM 87131

Gerald Leigh

New Mexico Engineering Research Institute

University of New Mexico

Campus P.O. Box 25

Albuquerque, NM 87131

Wally Beyer, General Manager

Verendrye Electric Cooperative

Velva, ND 58790

Lars Nygren

Manager, Minot Office

Verendrye Electric Cooperative, Inc. Minot, ND 58701

John Bohn

Chief Engineer

Vermont Electric Cooperative, Inc. School street

Johnson, VT 05656

Richard Cowart

Executive Director, Vermont

Environmental Board

Montpelier, VT 05602

Ray Anderson

Washington Energy office

400 E. Union

Olympia, WA 98504 
No. of

Copies

Lee Standley

Wells Rural Electric Company

P.O. Box 365

Wells, NV 89835

Dan Bryan

Wells Rural Electric Company

P.O. Box 365

Wells, NV 89835

Ed Macumber, Assistant Director Wyoming Energy Conservation Office Capitol Hall Building

25 th and Pioneer

Cheyenne, WY 82002

ONSITE

1 DOE Richland Operations Office

H. E. Ransom
No. of

Copies

37 Pacific Northwest Laboratory Battelle Boulevard

Richland, WA 99352

W. R. Barchet

C. E. Elderkin

D. L. Hadley

V. K. Hopkins (10)

A. H. Miller

E. L. Owczarski

W. T. Pennell

D. S. Renné (10)

J. M. Reeder

W. F. Sandusky

L. L. Wendell

R. K. Woodruff

Technical Information - Library (5)

Publishing Coordination (2) 


\section{$\cdot$}

